\title{
Effect of incremental amounts of camelina oil on milk fatty acid composition in lactating cows fed diets based on a mixture of grass and red clover silage and concentrates containing camelina expeller
}

\author{
A. Halmemies-Beauchet-Filleau, ${ }^{* 1}$ K. J. Shingfield, $\dagger \ddagger^{2}$ I. Simpura, ${ }^{*}$ T. Kokkonen, ${ }^{*}$ S. Jaakkola, ${ }^{*}$ V. Toivonen, $\dagger$ \\ and A. Vanhatalo* \\ *Department of Agricultural Sciences, Animal Science, Helsinki, PO Box 28, Fl-00014 University of Helsinki, Finland \\ †Green Technology, Natural Resources Institute Finland (Luke), FI-31600 Jokioinen, Finland \\ łInstitute of Biological, Environmental and Rural Sciences, Aberystwyth University, Aberystwyth, Ceredigion, SY23 3EB, United Kingdom
}

\begin{abstract}
Camelina is an ancient oilseed crop that produces an oil rich in cis-9, cis-12 18:2 (linoleic acid, LA) and cis9,cis-12,cis-15 18:3 ( $\alpha$-linolenic acid, ALA); however, reports on the use of camelina oil (CO) for ruminants are limited. The present study investigated the effects of incremental CO supplementation on animal performance, milk fatty acid (FA) composition, and milk sensory quality. Eight Finnish Ayrshire cows (91 d in milk) were used in replicated $4 \times 4$ Latin squares with 21-d periods. Treatments comprised 4 concentrates (12 $\mathrm{kg} / \mathrm{d}$ on an air-dry basis) based on cereals and camelina expeller containing 0 (control), 2, 4, or $6 \% \mathrm{CO}$ on an air-dry basis. Cows were offered a mixture of grass and red clover silage (RCS; 1:1 on a dry matter basis) ad libitum. Incremental $\mathrm{CO}$ supplementation linearly decreased silage and total dry matter intake, and linearly increased LA, ALA, and total FA intake. Treatments had no effect on whole-tract apparent organic matter or fiber digestibility and did not have a major influence on rumen fermentation. Supplements of $\mathrm{CO}$ quadratically decreased daily milk and lactose yields and linearly decreased milk protein yield and milk taste panel score from 4.2 to 3.6 [on a scale of 1 (poor) to 5 (excellent)], without altering milk fat yield. Inclusion of CO linearly decreased the proportions of saturated FA synthesized de novo (4:0 to 16:0), without altering milk fat 18:0, cis-9 18:1, LA, and ALA concentrations. Milk fat 18:0 was low $(<5 \mathrm{~g} / 100 \mathrm{~g}$ of FA) across all treatments. Increases in CO linearly decreased the proportions of total saturates from 58 to $45 \mathrm{~g} / 100 \mathrm{~g}$ of FA and linearly enriched trans-11 18:1, cis-9,trans-11 18:2, and trans-11,cis-15 18:2 from 5.2,
\end{abstract}

Received May 10, 2016.

Accepted September 30, 2016.

${ }^{1}$ Corresponding author: anni.halmemies@helsinki.fi

${ }^{2}$ Deceased.
2.6 , and 1.7 to $11,4.3$, and $5.8 \mathrm{~g} / 100 \mathrm{~g}$ of FA, respectively. Furthermore, CO quadratically decreased milk fat trans-10 18:1 and linearly decreased trans-10,cis-12 18:2 concentration. Overall, milk FA composition on all treatments suggested that one or more components in camelina seeds may inhibit the complete reduction of 18-carbon unsaturates in the rumen. In conclusion, $\mathrm{CO}$ decreased the secretion of saturated FA in milk and increased those of the trans-11 biohydrogenation pathway or their desaturation products. Despite increasing the intake of 18-carbon unsaturated FA, CO had no effect on the secretions of 18:0, cis-9 18:1, LA, or ALA in milk. Concentrates containing camelina expeller and $2 \%$ CO could be used for the commercial production of low-saturated milk from grass- and RCS-based diets without major adverse effects on animal performance.

Key words: camelina, saturated fatty acid, trans fatty acid, conjugated linoleic acid

\section{INTRODUCTION}

Public health policies recommend a population-wide decrease in the consumption of SFA and an increase in PUFA, specifically n-3 fatty acids (FA), to lower the incidence of cardiovascular and metabolic diseases (FAO, 2010; USDA-USDHHS, 2010; Perk et al., 2012). Milk and dairy products contribute to total fat intake and are typically the major source of SFA in the human diet (Kliem and Shingfield, 2016). Ruminant milk fat also contains several FA with antimutagenic properties, including 4:0, odd- and branched-chain FA (OBCFA), trans-11 18:1, and cis-9,trans-11 CLA (Parodi, 2001; Shingfield et al., 2008b). Altering milk fat composition offers the opportunity to lower SFA intake and increase the consumption of PUFA and bioactive lipids without requiring a change in eating habits.

Diet is the major environmental factor influencing milk fat composition. Forage species, forage conservation methods, and dietary lipid supplements are known 
to affect milk FA composition (Dewhurst et al., 2006; Shingfield et al., 2013). Several studies have examined the potential to lower SFA and enrich trans-11 18:1, cis9,trans-11 CLA, and cis-9,cis-12,cis-15 18:3 ( $\alpha$-linolenic acid, ALA) in milk fat using oils or processed seeds rich in ALA principally from linseed (Chilliard et al., 2009; Kliem and Shingfield, 2016). Interest in cultivating camelina (Camelina sativa) as an alternative to linseed has been increasing due to low input requirements, a high drought tolerance, and an ability to adapt to changes in climatic and soil conditions (Zubr, 2003a). Camelina oil $(\mathbf{C O})$ is a rich source of 18 -carbon $\mathrm{n}-6$ PUFA in the form of cis-9,cis-12 18:2 [linoleic acid (LA); 15 to $16 \mathrm{~g} / 100 \mathrm{~g}$ of FA] and n-3 PUFA (ALA; 37 to $38 \mathrm{~g} / 100 \mathrm{~g}$ of FA; Zubr, 2003b; Bayat et al., 2015). Camelina seeds are also relatively abundant in essential AA (Zubr, 2003b), highlighting the potential of camelina as a high-quality feed for ruminants.

It is well established that the amount of supplemental lipid and the composition of the basal diet are important determinants of milk FA responses to plant oils and oilseeds in lactating cows (Roy et al., 2006; Shingfield et al., 2013). Both factors also influence DMI, milk yield, and milk fat content (Roy et al., 2006; Drackley et al., 2007; Steinshamn, 2010). Milk fat from cows fed red clover silage (RCS; Trifolium pratense) contains higher concentrations of ALA compared with grass silage (Dewhurst et al., 2006; Steinshamn, 2010; Halmemies-Beauchet-Filleau et al., 2014). However, owing to inconsistencies in annual herbage yield, red clover is typically cultivated as a mixed sward with grasses rather than as a monoculture. Feeding grass silage and RCS as a mixture often increases DMI and milk yield compared with feeding grass or RCS as sole forages (Vanhatalo et al., 2009; Halmemies-Beauchet-Filleau et al., 2014). Several studies have shown that camelina seeds or CO can be used to alter milk fat composition in cows fed diets based on maize silage (Hurtaud and Peyraud, 2007), RCS (Halmemies-Beauchet-Filleau et al., 2011), or grass silage (Mihhejev et al., 2007; Bayat et al., 2015) and in goats (Pikul et al., 2014) and sheep (Szumacher-Strabel et al., 2011) based on a mixture of alfalfa silage, grass silage, and meadow hay. However, no single experiment has examined the effect of $\mathrm{CO}$ inclusion rate in cows fed diets containing a mixture of grass silage and RCS.

The aim of this study was to determine the optimal amount of CO for altering milk FA composition without causing adverse effects on DMI or milk production in cows fed diets based on a mixture of grass silage and RCS supplemented with concentrates containing camelina expeller as the main protein source. Eight cows were used in a replicated $4 \times 4$ Latin square to test the hypotheses that (1) incremental inclusion of $\mathrm{CO}$ progressively lowers DMI and milk fat medium-chain SFA secretion, and (2) supplements of CO increase milk fat cis-9,trans-11 CLA and ALA concentrations in a dose-dependent manner.

\section{MATERIALS AND METHODS}

\section{Animals, Experimental Design, and Experimental Diets}

All experimental procedures were approved by the National Animal Ethics Committee (Hämeenlinna, Finland) in accordance with guidelines established by the European Union (1986). The experiment was performed at the University of Helsinki research farm in Viikki, Finland. Eight multiparous Finnish Ayrshire cows of (mean $\pm \mathrm{SD}$ ) $634 \pm 68.5 \mathrm{~kg}$ of BW, $91 \pm 16.5$ DIM, and producing $37.7 \pm 2.60 \mathrm{~kg}$ of milk/d were used. Four cows were fitted with rumen cannulas (100 mm i.d.; Bar Diamond Inc., Parma, ID). Cows were allocated at random to experimental diets according to a replicated $4 \times 4$ Latin square design with 21 -d periods (Supplemental Table S1; https://doi.org/10.3168/ jds.2016-11438). At the end of the experiment, cows weighed on average $630 \mathrm{~kg}$ (SD $72.2 \mathrm{~kg}$ ). Treatments comprised 4 pelleted concentrate supplements based on cereals and camelina expeller containing 0 (control), 2,4 , or $6 \%$ of $\mathrm{CO}$ on an air-dry basis. Cows received $12 \mathrm{~kg} / \mathrm{d}$ of concentrates on an air-dry basis (Table 1) fed as equal meals at 0615, 1000, 1300, 1645, and 2000 $\mathrm{h}$, with ad libitum access to a mixture of grass silage and RCS (1:1 on a DM basis). Fresh silage was made available 4 times daily: 0700, 1200, 1500, and $1800 \mathrm{~h}$. Experimental diets were designed to meet ME and MP requirements and to support maintenance and $40 \mathrm{~kg}$ of ECM/d (Luke, 2015). All experimental animals were housed in individual tiestalls equipped with forage intake control feeding stations (Insentec BV, Marknesse, the Netherlands) that were fitted with separate concentrate troughs. Cows had continuous access to water and were milked twice daily at 0615 and $1700 \mathrm{~h}$.

Grass silage was prepared on June 16, 2008, from primary growths of a 2-yr ley of mixed timothy (Phleum pratense, $83 \%$ of DM) and meadow fescue (Festuca pratensis, $13 \%$ of DM) containing small amounts of cocksfoot (Dactylis glomerata), weeds, and dead plant material (1, 2, and 1\% of DM, respectively). On April 25 , grass swards used for silage production were fertilized with $\mathrm{N}, \mathrm{P}$, and $\mathrm{K}$ at a rate of 97,16 , and $16 \mathrm{~kg} / \mathrm{ha}$, respectively. On reaching the heading stage, grass was cut with a mower-conditioner, wilted for approximately $5 \mathrm{~h}$ to a DM content of $27.7 \%$, and ensiled using a formic acid-based additive $(760 \mathrm{~g}$ of formic acid and $55 \mathrm{~g}$ of ammonium formate, AIV 2 Plus, Kemira Ltd., 
Helsinki, Finland) applied at a rate of $6 \mathrm{~L} / \mathrm{t}$ fresh herbage and roundbaled. Primary growths of 2-yr red clover leys were cut at an early flowering stage on July 1, 2008, with a mower-conditioner, wilted for $48 \mathrm{~h}$ during inclement weather to a final DM content of $14.8 \%$, harvested with a self-loading wagon, and ensiled using formic acid based additive $(6 \mathrm{~L} / \mathrm{t}$ fresh herbage, AIV 2 Plus) in a clamp silo. Before harvesting, red clover swards were fertilized on April 28 with N, P, and K at a rate of $4.1,10$, and $42 \mathrm{~kg} / \mathrm{ha}$, respectively.

\section{Sampling and Chemical Analysis}

Individual cow intakes were recorded throughout the experiment, but only measurements for the penultimate $6 \mathrm{~d}$ of each period (d 15 to 20) were used for statistical analysis. Representative samples of feeds (d 15 to 21) and spot fecal samples (at 0700 and $1500 \mathrm{~h}$ on d 17 to 21) were collected, composited, and stored at $-20^{\circ} \mathrm{C}$ before chemical analysis (Kokkonen et al., 2000). The concentration of indigestible NDF of silages and concentrates was determined in duplicate by incubating samples (from 0.5 to $1.0 \mathrm{~g}$ ) within polyester bags $(60 \times$ $120 \mathrm{~mm}$, pore size $17 \mu \mathrm{m}$ ) in the rumen for $12 \mathrm{~d}$ (Ahvenjärvi et al., 2000). The OM content of the indigestible residue was determined by ashing at $600^{\circ} \mathrm{C}$ for 18 h (Heraeus K1253, Heraeus GmbH, Hanau, Germany). Ethanol was analyzed using a commercially available kit (Cat. No 10176290035, Boehringer-Mannheim, Darmstadt, Germany) in accordance with the instructions of the manufacturer with a UV-spectrophotometer (Shimadzu UV-VIS mini 1240, Shimadzu Europa GmbH, Duisburg, Germany). Nutrient digestibility

Table 1. Formulation and ingredient composition of experimental concentrates ( $\%$ on an air-dry basis)

\begin{tabular}{|c|c|c|c|c|}
\hline \multirow[b]{2}{*}{ Item } & \multicolumn{4}{|c|}{ Experimental concentrate, $\%$ camelina oil } \\
\hline & 0 & 2 & 4 & 6 \\
\hline Barley & 24.3 & 23.5 & 23.0 & 22.0 \\
\hline Wheat & 24.0 & 23.5 & 23.0 & 22.2 \\
\hline Camelina expeller & 20.0 & 20.0 & 20.0 & 20.0 \\
\hline $\begin{array}{l}\text { Molassed sugar-beet } \\
\text { pulp }\end{array}$ & 24.0 & 23.2 & 22.2 & 22.0 \\
\hline Sugar-beet molasses & 5.0 & 5.0 & 5.0 & 5.0 \\
\hline Camelina seed oil & - & 2.0 & 4.0 & 6.0 \\
\hline Calcium carbonate & 1.0 & 1.1 & 1.1 & 1.1 \\
\hline Sodium bicarbonate & 0.4 & 0.5 & 0.5 & 0.5 \\
\hline Sodium chloride & 0.3 & 0.3 & 0.3 & 0.3 \\
\hline Magnesium oxide & 0.4 & 0.4 & 0.4 & 0.4 \\
\hline Biotin & 0.2 & 0.2 & 0.2 & 0.2 \\
\hline Mineral premix ${ }^{1}$ & 0.3 & 0.3 & 0.3 & 0.3 \\
\hline Vitamin premix ${ }^{2}$ & 0.2 & 0.2 & 0.2 & 0.2 \\
\hline
\end{tabular}

was estimated using acid-insoluble ash as an internal marker (Kokkonen et al., 2000). Cows were weighed (CV 9600 Scale, Solotop Ltd., Helsinki, Finland) over 2 consecutive days at the beginning and the end of the experiment. Body condition scores were recorded on a scale of 1 (thin) to 5 (fat) at the start of the experiment and at the end of each experimental period (Edmonson et al., 1989).

Samples of ruminal fluid were collected from cows fitted with a rumen cannula on 8 occasions over 1.5 -h intervals starting at $0600 \mathrm{~h}$ on $\mathrm{d} 19$ of each period, filtered through a single layer of cheesecloth, and analyzed for $\mathrm{pH}$, ammonia N, and VFA (Koivunen et al., 2015). To assess rumen protozoal numbers, a 10-mL sub-sample of filtered rumen fluid was taken and preserved with $30 \mathrm{~mL}$ of aqueous $\mathrm{NaCl}(0.9 \% \mathrm{wt} / \mathrm{vol})$ containing $10 \%$ (vol/vol) $\mathrm{CH}_{2} \mathrm{O}$. Samples collected at each time point were composited and replicate $(\mathrm{n}=6)$ measurements of protozoal numbers were made using a counting chamber (Fuchs-Rosenthal, Fortuna, Germany).

On d 21 of each period, blood samples were obtained from the coccygeal vessels at 0530, 0830, and 1130 $\mathrm{h}$ into evacuated collection tubes (Venoject, Terumo Europe Ltd., Leuven, Belgium) containing potassium EDTA and placed on ice. Once collected, blood samples were centrifuged $(15 \mathrm{~min}$ at $870 \times g$ at room temperature) and plasma was stored at $-20^{\circ} \mathrm{C}$ pending analysis for BHB, glucose, insulin, nonesterified fatty acids (NEFA; Selim et al., 2014), and acetic acid. Concentrations of acetic acid were determined by ultrahigh performance liquid chromatography (Waters Acquity UPLC, Waters, Milford, MA). After thawing at room temperature, plasma $(0.1 \mathrm{~mL})$ was deproteinized following the addition of $0.1 \mathrm{~mL}$ of acetonitrile. The mixture was centrifuged $(10 \mathrm{~min}$ at $15,000 \times \mathrm{g})$, and $40 \mu \mathrm{L}$ of the supernatant was used in a conjugation reaction with $40 \mu \mathrm{L}$ of 1-ethyl-3-(3-dimethylaminopropyl)carbodiimide $(100 \mathrm{mM})$ in ethanol containing $3 \%$ pyridine and $40 \mu \mathrm{L}$ of pentafluorobenzylhydroxylamine $(50 \mathrm{mM})$ in 50\%/50\% acetonitrile/300 $\mathrm{mM} \mathrm{KH}_{2} \mathrm{PO}_{4}$ solution. Solutions were combined, mixed thoroughly, and incubated for $30 \mathrm{~min}$ at $60^{\circ} \mathrm{C}$. Chromatography was achieved using $0.35 \%$ formic acid in milliQ water and $0.1 \%$ formic acid in acetonitrile (eluents A and B, respectively), using a MassTrak AAA $2.1 \times 150 \mathrm{~mm}$ column (Waters) maintained at $60^{\circ} \mathrm{C}$, and a gradient method (initial to $1 \mathrm{~min}=75 \%$ A, $5.2 \mathrm{~min}=54 \%$ $\mathrm{A}, 5.5 \mathrm{~min}$ to $6 \mathrm{~min}=10 \% \mathrm{~A}, 6.5 \mathrm{~min}$ to $7.5 \mathrm{~min}$ $=75 \% \mathrm{~A}$ ). Initial solvent flow rate was $0.45 \mathrm{~mL} / \mathrm{min}$ that was increased to $0.5 \mathrm{~mL} / \mathrm{min}$ from $1 \mathrm{~min}$ to 5.2 min and reversed to $0.45 \mathrm{~mL} / \mathrm{min}$ from $5.2 \mathrm{~min}$ to 5.5 min. Concentrations of acetate were determined for a sample volume of $1 \mu \mathrm{L}$ and monitoring column effluent at $269 \mathrm{~nm}$. Standard solutions of an authentic standard 
(A6283, Sigma-Aldrich, Helsinki, Finland) over a range in concentrations from $46 \mu M$ to $1.15 \mathrm{~m} M$ were used to check the linearity of responses and to develop a calibration curve.

Milk yield was recorded daily throughout the experiment, but only measurements made from d 15 through d 20 of each period were used for statistical analysis. Samples of milk were collected from each cow over 4 consecutive milkings starting at $1700 \mathrm{~h}$ on d 19. Milk samples $(20 \mathrm{~mL})$ treated with preservative (Bronopol, Valio Ltd., Helsinki, Finland) were analyzed for milk fat, CP, urea, and lactose (Milko-Scan605 analyzer, Foss Electric, Hillerød, Denmark). Additional samples of unpreserved milk $(500 \mathrm{~mL})$ were also collected, composited according to yield, and stored at $-20^{\circ} \mathrm{C}$ until analyzed for FA composition. Sensory analysis was performed on milk samples $(750 \mathrm{~mL})$ collected over 2 consecutive milkings, starting at $1700 \mathrm{~h}$ on $\mathrm{d} 18$, that had been placed in an ice-bath immediately after collection, and stored at $4^{\circ} \mathrm{C}$ thereafter. Assessment of aroma and flavor of unpasteurized milk were made on d 19 by an experienced 6-member taste panel. Milk samples were presented to the panel at $15^{\circ} \mathrm{C}$ and evaluated using a numeric interval scale from 1 (poor) to 5 (excellent) as outlined previously (Halmemies-Beauchet-Filleau et al., 2011). For the determination of butter storage properties, all milk from both cows fed the same treatment within each period was pooled over 3 consecutive milkings starting at $0615 \mathrm{~h}$ on $\mathrm{d} 18$. Immediately after milking, milk was transferred into stainless steel 50-L containers and placed in a water bath containing ice to facilitate rapid cooling. Milk was stored at $4^{\circ} \mathrm{C}$ until butter manufacture in the dairy pilot plant of the Department of Food Technology, University of Helsinki (Helsinki, Finland). Milk was passed through a Seital SE 02 separator (Seital Separatori Italia, Santorso, Italy) and the cream obtained was pasteurized at $90^{\circ} \mathrm{C}$ for $25 \mathrm{~s}$ (Fischer E 5 FHG plate heat exchanger, Fischer AG, Ebreichsdorf, Austria). Pasteurized cream was ripened and the cream was churned (Elba 30, Elecrem, Chatillon, France). Sub-samples of butter (from 1 to $2 \mathrm{~g}$ ) were used to determine water content by drying to a constant weight loss at $102^{\circ} \mathrm{C}$. Concentrations of peroxides (Halmemies-Beauchet-Filleau et al., 2011) and NEFA in butter were determined immediately after manufacture and at 2-wk intervals until 12 wk of storage. Butterfat acidity (NEFA \%) was determined with an automatic titrator (DL-58, Mettler-Toledo, Greifensee, Switzerland) equipped with a photoelectrode (DP550, Mettler-Toledo) according to International Dairy Federation Standard 6 (IDF, 2004) with minor modifications. A quality assurance sample was prepared by adding a known amount of cis-9 18:1 in refined rapeseed oil, and benzoic acid was used in- stead of potassium hydrogen phthalate to validate the tetra- $n$-butylammonium hydroxide titer. Results are expressed as a weight percentage of cis-9 18:1 in butterfat. Butters were tasted and a verbal description of flavor chracteristics was provided by trained panelists.

\section{Lipid Analysis}

Lipid in 1-mL milk samples was extracted in triplicate with a mixture of ammonia, methanol, diethylether, and hexane (0.2:1:2.5:2.5, vol/vol, respectively). Organic extracts were combined and converted to FAME using methanolic sodium methoxide as a catalyst (Halmemies-Beauchet-Filleau et al., 2011).

Samples of FAME were quantified using a gas chromatograph (model 6890, Hewlett-Packard, Wilmington, DE) equipped with a flame-ionization detector, automatic injector, split injection port, and a 100-m fused silica capillary column (i.d. $0.25 \mathrm{~mm}$ ) coated with a $0.2-\mu \mathrm{m}$ film of cyanopropyl polysiloxane (CP-Sil 88, Chromopack 7489, Middelburg, the Netherlands). Total FAME profile in a $2-\mu \mathrm{L}$ sample at a split ratio of 1:50 was determined using a temperature gradient program and hydrogen as a carrier gas operated at constant pressure $(137.9 \mathrm{kPa})$ at a flow rate of $0.5 \mathrm{~mL} /$ min. Isomers of 18:1 were further resolved in a separate analysis under isothermal conditions at $170^{\circ} \mathrm{C}$. Peaks were identified by comparison of retention times with authentic FAME standards. Fatty acid methyl esters not available as commercial standards were identified based on GC-MS analysis of 4,4-dimethyloxoline (DMOX) derivatives prepared from FAME. Preparation of DMOX derivatives, parameters used for GC-MS analysis, and the interpretation of mass spectra were in accordance with earlier reports (Halmemies-Beauchet-Filleau et al., 2011). Relative retention time and order of elution were used to differentiate between diastereomers of 3,7,11,15-tetramethyl-16:0 (Schröder and Vetter, 2011).

The distribution of CLA isomers in milk samples was determined using a HPLC system (model 1090; Hewlett-Packard, Wilmington, DE) equipped with 4 silver-impregnated silica columns (Chrom-Spher 5 Lipids, $250 \times 4.6 \mathrm{~mm}, 5-\mu \mathrm{m}$ particle size; Varian Ltd., Walton-on-Thames, UK) coupled in series. Methyl esters of CLA were separated under isothermal conditions at $22^{\circ} \mathrm{C}$ using $0.1 \%$ ( $\mathrm{vol} / \mathrm{vol}$ ) acetonitrile in heptane at a flow rate of $1 \mathrm{~mL} / \mathrm{min}$ and monitoring column effluent at 233 and $210 \mathrm{~nm}$ (Halmemies-Beauchet-Filleau et al., 2011).

Milk FA composition was expressed as a weight percentage of total FA using theoretical relative response factors to account for the carbonyl deficiency in the flame-ionization detector response for 4- to 10-carbon containing FAME (Halmemies-Beauchet-Filleau et al., 
2011). Concentrations of specific conjugated isomers were calculated based on proportionate peak area responses determined by HPLC and the sum of trans7,cis-9 CLA, trans-8,cis-10 CLA, and cis-9,trans-11 CLA weight percentage determined by GC.

\section{Calculations}

Digestible organic matter content in silage DM (DOMD) was calculated from measurements of pepsin-cellulase solubility (Koivunen et al., 2015). Metabolizable energy content of experimental concentrates was calculated as the weighted sum of published energy concentrations of individual ingredients (Luke, 2015). The ME content of silage was calculated based on DOMD content (Luke, 2015). Metabolizable energy intakes were corrected for associative effects according to Luke (2015). Energy requirements (MJ/d) for maintenance and milk production was calculated as $\mathrm{BW}^{0.75}$ $(\mathrm{kg}) \times 0.515+\mathrm{ECM}$ yield $(\mathrm{kg} / \mathrm{d}) \times 5.15($ Luke, 2015) , where $\mathrm{BW}^{0.75}=$ metabolic BW. Energy-corrected milk yield was calculated as milk yield $(\mathrm{kg}) \times[383 \times$ fat $(\%)+242 \times$ protein $(\%)+165.4 \times$ lactose $(\%)+$ 20.7]/3,140 (Sjaunja et al., 1990).

\section{Statistical Analysis}

Data were analyzed by ANOVA using a model that included the random effect of cow within square and fixed effects of square, period within square, carryover, and treatment using the PROC MIXED procedure of SAS (version 9.3, SAS Institute Inc., Cary, NC). For all parameters, the effect due to carryover was $P>0.10$, and this term was therefore removed from the final statistical model. Sums of squares for treatment effects were further separated using orthogonal contrasts into single degree of freedom comparisons to test for the significance of linear, quadratic, and cubic components of response to incremental amounts of $\mathrm{CO}$ in the diet. Least squares means are reported with treatment effects declared significant at $P \leq 0.05$, with $P$ values between 0.05 and 0.10 considered a trend toward significance.

Unfortunately, 4 of 32 cow-period observations could not be made (Supplemental Table S1; https://doi. org/10.3168/jds.2016-11438) due to a leg injury (cow number 3 during period 1) or digestive disorders (cow number 6 during periods 3 and 4). Furthermore, cow number 5 was replaced with a different cow due to digestive disorders after period 1.

Measurements of rumen $\mathrm{pH}$ and fermentation characteristics were analyzed by ANOVA for repeated measures using a model that included the fixed effects of treatment, period, sampling time, the interaction of sampling time and period and that of sampling time with treatment and the random effects of cow, the interaction of cow, treatment, and period and the interaction of cow and sampling time using the Satterthwaite correction. The covariance structure AR(1) was applied with the interaction of cow and period as the subject for repeated measures. Time by treatment interactions were not significant; therefore, daily averages are reported. Changes in the concentration of peroxides and NEFA during butter storage were analyzed by ANOVA for repeated measures using a model that included the fixed effect of treatment, period, time, the interactions of time and period and time and treatment, and the random effect of the interaction of treatment and period with the Satterthwaite correction. The AR(1) covariance structure was applied with diet within period as the subject for repeated measures.

\section{RESULTS}

\section{Chemical Composition of Experimental Feeds}

The chemical composition of concentrate treatments and experimental silages is presented in Table 2. Due to a prolonged period of rain around harvesting, the DM content of red clover was lower than targeted. Red clover silage was of moderate fermentation quality and nutritive value, as indicated by the relatively high $\mathrm{pH}$ and concentrations of VFA and ammonia $\mathrm{N}$ and low DOMD, whereas grass silage was of high fermentation quality and digestibility. Compared with grass silage, RCS had higher ash and CP contents and lower NDF content. However, total FA content and FA composition were similar between grass silage and RCS. For both silages, ALA was the major FA (from 45 to 49 $\mathrm{g} / 100 \mathrm{~g}$ of total FA), but RCS and grass silage also contained relatively high proportions of 16:0 (from 15 to $17 \mathrm{~g} / 100 \mathrm{~g}$ of total FA) and LA (from 17 to $19 \mathrm{~g} / 100$ $\mathrm{g}$ of total FA). By design, experimental concentrates contained different amounts of FA ranging from 44 to $91 \mathrm{~g} / \mathrm{kg}$ of DM, with CO inclusion being associated with incremental changes in the relative proportions of 16:0, cis-9 18:1, LA, ALA, and cis-11 20:1 in total lipid from $12,16,32,20$, and 7 to $8,14,23,25$, and $15 \mathrm{~g} / 100$ $\mathrm{g}$ of total FA, respectively.

\section{Nutrient Intake}

Cows consumed all concentrates on the 0 and $2 \%$ $\mathrm{CO}$ treatments but, on occasion, small amounts of the $4 \%$ and $6 \% \mathrm{CO}$ concentrates were refused. Increasing levels of dietary CO linearly decreased $(P<0.01)$ silage 
Table 2. Chemical composition of experimental feeds

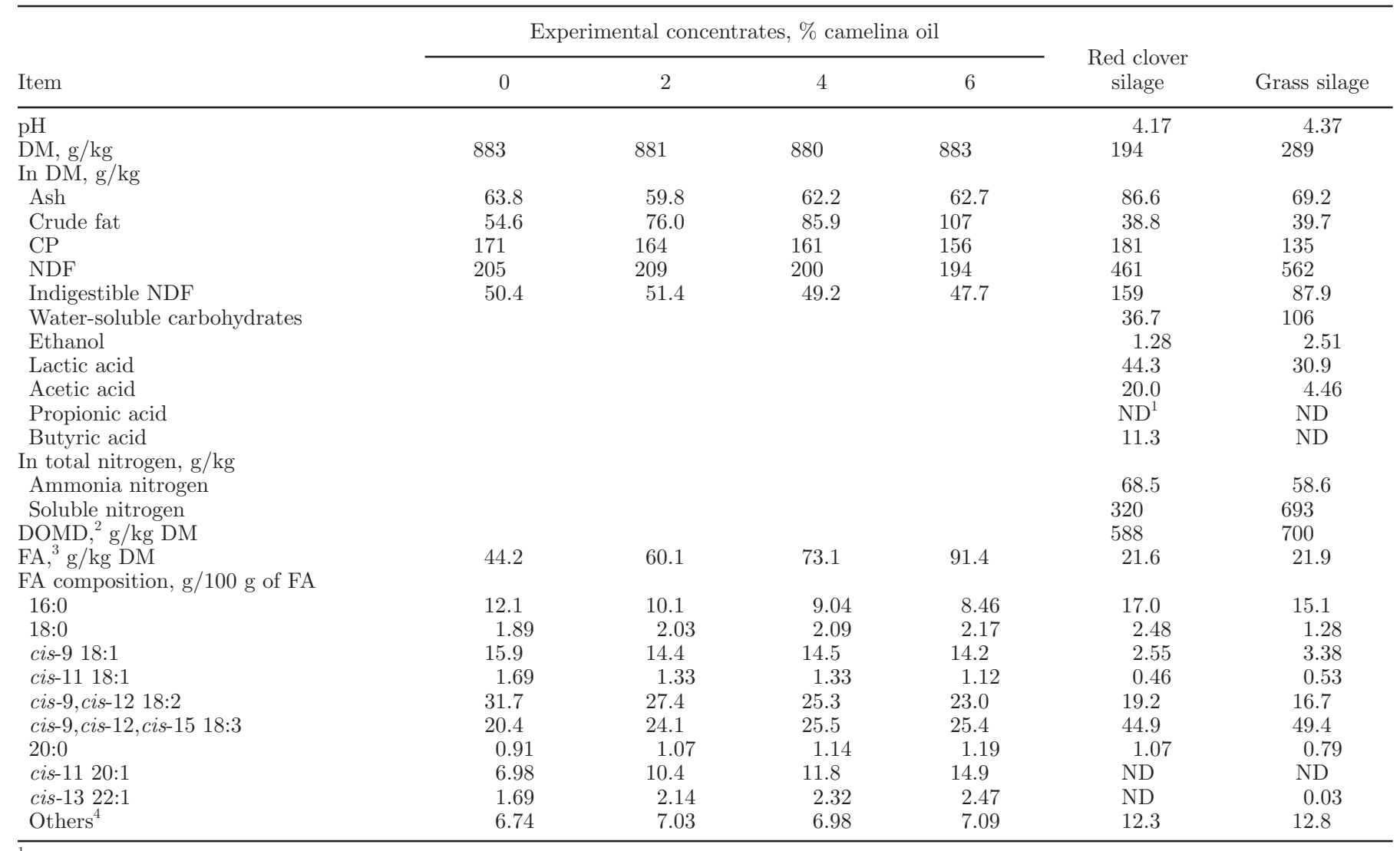

\footnotetext{
${ }^{1}$ Not detected.
}

${ }^{2}$ Digestible OM content in silage DM.

${ }^{3}$ Fatty acid.

${ }^{4}$ Includes 12:0, anteiso 13:0, iso 13:0, 14:0, iso 14:0, 15:0, anteiso 15:0, iso 15:0, cis-6+7+8 16:1, cis-9 16:1, trans-3 16:1, trans-5 16:1, trans-6 16:1, trans-9 16:1, 17:0, anteiso 17:0, iso 17:0, iso 18:0, 10-O-18:0, cis-10 18:1, trans-9 18:1, trans-10 18:1, trans-11 18:1, trans-12 18:1, cis-9,trans-11 18:2, cis-9,trans-12 18:2, trans-9,cis-12 18:2, trans-9,trans-12 18:2, cis-9,cis-12,trans-15 18:3 + trans-9,trans-12,cis-15 18:3, cis-9,trans-12,cis-15 18:3, cis-9,trans-12,trans-15 18:3, cis-6,cis-9,cis-12,cis-15 18:4, 19:0, cis-10 19:1, S3,R7,R11,15-tetramethyl-16:0, cis-8 20:1, cis-9 20:1, cis-13 20:1, trans-11 20:1, cis-11,cis-14 20:2, cis-11,cis-14,cis-17 20:3, cis-5,cis-8,cis-11,cis-14,cis-17 20:5, 21:0, 22:0, cis-13,cis-16 22:2, cis-13,cis-16,cis-19 20:3, cis-9,cis-12,cis-15,cis-18 22:4, 23:0, cis-14 23:1, 24:0, cis-14 24:1, cis-15 24:1, 25:0, 26:0, 27:0, 28:0, 29:0, 30:0, and 26 unidentified FA.

and diet DM intakes (Table 3). Overall, the proportion of concentrate in the diet DM increased linearly $(P<$ 0.04 ) from 50 to $55 \%$ in response to incremental $\mathrm{CO}$ supplementation. Furthermore, CO inclusion linearly decreased $(P<0.01) \mathrm{ME}, \mathrm{OM}, \mathrm{NDF}$, and $\mathrm{N}$ intake, but linearly increased $(P<0.05)$ the intake of 16 - to 22-carbon FA (Table 3 ).

\section{Rumen Fermentation and Nutrient Digestibility}

Dietary CO supplementation had no effect $(P>$ 0.10 ) on rumen $\mathrm{pH}$, ammonia $\mathrm{N}$, and total VFA concentrations or on rumen protozoal numbers (Table 3, Supplemental Figure S1; https://doi.org/10.3168/ jds.2016-11438). Rumen $\mathrm{pH}$ varied between 5.93 to 7.13 across sampling times (Supplemental Figure S1), averaging 6.50 across all treatments and sampling times
(Table 3). Incremental CO supplementation had no major effect $(P \geq 0.09)$ on the molar proportions of individual VFA in rumen fluid (Table 3). Increasing amounts of $\mathrm{CO}$ had no effect $(P>0.10)$ on whole-tract apparent nutrient digestion, except for a linear increase $(P<0.01)$ in crude fat digestibility (Table 3$)$.

\section{Plasma Metabolites}

Plasma BHB tended to be higher $(P=0.07$, cubic effect) on the $4 \% \mathrm{CO}$ treatment compared with the other diets (Table 3). Plasma acetic acid concentration linearly decreased $(P<0.02)$ in response to $\mathrm{CO}$. Incremental CO supplementation linearly increased $(P$ $<0.01)$ plasma NEFA concentration with a numerical linear decrease $(P=0.11)$ in plasma glucose and insulin. 
Table 3. Effect of incremental amounts of camelina oil on nutrient intake, rumen fermentation, whole-tract apparent nutrient digestibility, and plasma metabolite concentration

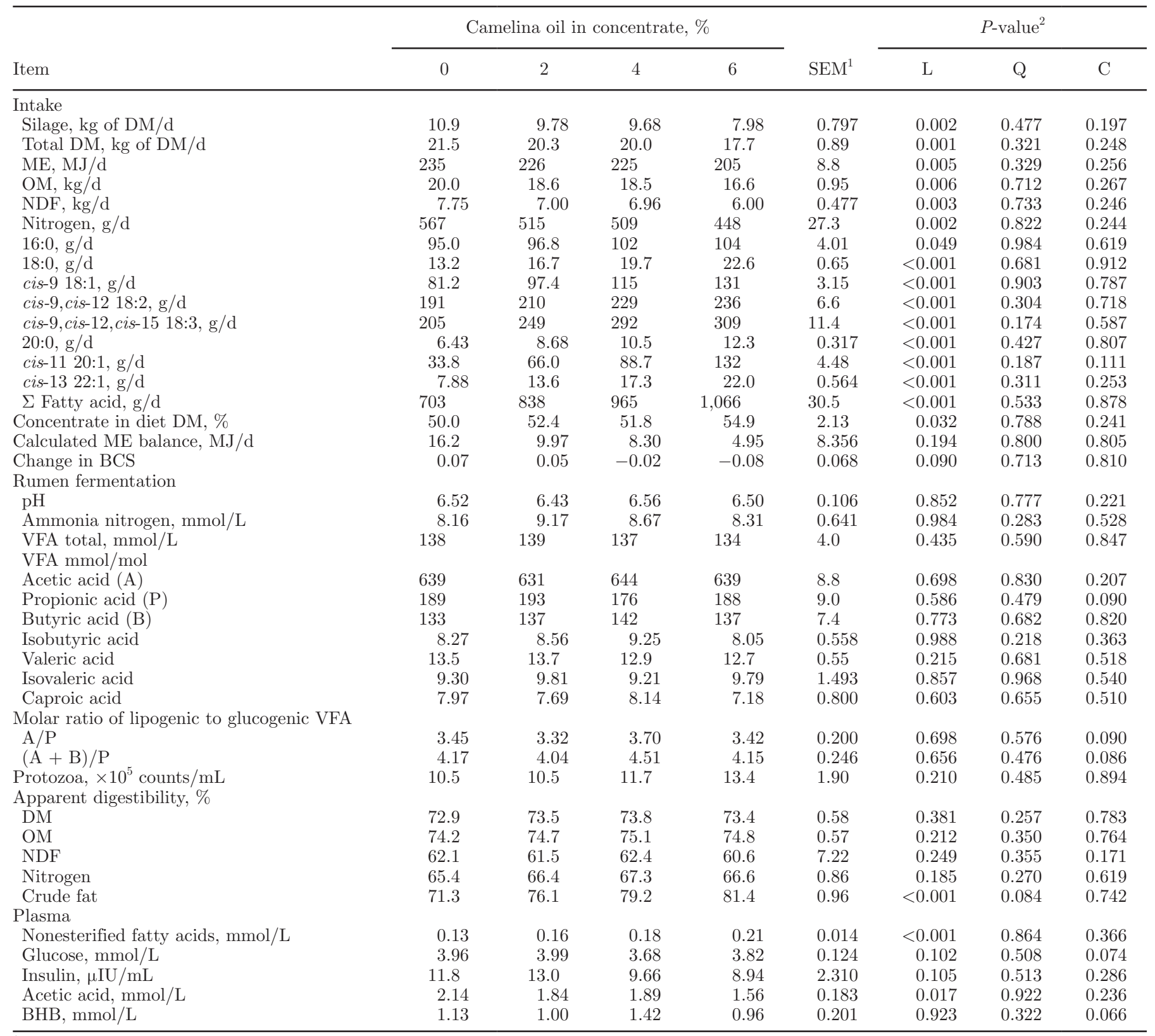

${ }^{1}$ SEM for the $4 \%$ camelina oil treatment. SEM for 0,2 , and $6 \%$ camelina oil treatments are proportionately $0.954,0.921$, and 0.955 of the reported value, respectively. For rumen fermentation characteristics, SEM are for the $0 \%$ camelina oil treatment. SEM for 2 , 4 , and $6 \%$ camelina oil treatments are proportionately $0.886,0.998$, and 0.998 of the reported value, respectively.

${ }^{2}$ Significance of linear (L), quadratic (Q), and cubic (C) components of the response to incremental inclusion of camelina oil in concentrates fed at $12 \mathrm{~kg} / \mathrm{d}$ on an air-dry basis to cows receiving a mixture (1:1 on a DM basis) of grass silage and red clover silage.

\section{Milk Production, Milk Sensory Quality, and Butter Storage Properties}

The effect of $\mathrm{CO}$ treatments on milk production and milk sensory quality is shown in Table 4. Incremental $\mathrm{CO}$ supplementation decreased $(P<0.03)$ milk yield in a quadratic manner and linearly decreased $(P<0.01)$
ECM yield. Inclusion of CO had no effect $(P>0.10)$ on milk fat output, but linearly increased $(P<0.02)$ milk fat concentration. Supplements of CO linearly decreased $(P<0.04)$ milk protein yield and milk protein and urea concentrations. Increases in $\mathrm{CO}$ had no effect on milk lactose concentration $(P>0.10)$, but decreased $(P<0.02)$ milk lactose yield in a quadratic manner. 
Table 4. Effect of incremental amounts of camelina oil on milk production, milk composition, and milk sensory quality

\begin{tabular}{|c|c|c|c|c|c|c|c|c|}
\hline \multirow[b]{2}{*}{ Item } & \multicolumn{4}{|c|}{ Camelina oil in concentrate, $\%$} & \multirow[b]{2}{*}{$\mathrm{SEM}^{1}$} & \multicolumn{3}{|c|}{$P$-value ${ }^{2}$} \\
\hline & 0 & 2 & 4 & 6 & & $\mathrm{~L}$ & $\mathrm{Q}$ & $\mathrm{C}$ \\
\hline \multicolumn{9}{|l|}{ Yield } \\
\hline Milk, kg/d & 33.5 & 32.5 & 32.3 & 28.0 & 1.38 & $<0.001$ & 0.022 & 0.108 \\
\hline $\mathrm{ECM},{ }^{3} \mathrm{~kg} / \mathrm{d}$ & 29.9 & 29.3 & 29.4 & 26.1 & 1.82 & 0.007 & 0.094 & 0.210 \\
\hline Fat, g/d & 1,117 & 1,123 & 1,148 & 1,055 & 99.5 & 0.438 & 0.261 & 0.479 \\
\hline Protein, g/d & 1,027 & 962 & 946 & 815 & 48.6 & $<0.001$ & 0.140 & 0.107 \\
\hline Lactose, $\mathrm{g} / \mathrm{d}$ & 1,554 & 1,507 & 1,499 & 1,287 & 71.9 & $<0.001$ & 0.014 & 0.081 \\
\hline \multicolumn{9}{|l|}{ Concentration } \\
\hline Fat, $\mathrm{g} / \mathrm{kg}$ & 32.7 & 34.7 & 36.1 & 37.4 & 2.73 & 0.014 & 0.762 & 0.938 \\
\hline Protein, $\mathrm{g} / \mathrm{kg}$ & 30.7 & 29.6 & 29.3 & 29.1 & 0.54 & 0.032 & 0.313 & 0.650 \\
\hline Lactose, $\mathrm{g} / \mathrm{kg}$ & 46.3 & 46.4 & 46.6 & 45.8 & 0.61 & 0.287 & 0.168 & 0.428 \\
\hline Urea, $\mathrm{mmol} / \mathrm{L}$ & 6.20 & 5.20 & 4.35 & 3.62 & 0.505 & $<0.001$ & 0.663 & 0.994 \\
\hline Milk taste panel score ${ }^{4}$ & 4.15 & 3.80 & 3.78 & 3.56 & 0.156 & 0.018 & 0.675 & 0.416 \\
\hline
\end{tabular}

${ }^{1}$ SEM for the $4 \%$ camelina oil treatment. SEM for 0,2 , and $6 \%$ camelina oil treatments are proportionately $0.954,0.921$, and 0.955 of the reported value, respectively.

${ }^{2}$ Significance of linear (L), quadratic (Q), and cubic (C) components of the response to incremental inclusion of camelina oil in concentrates fed at $12 \mathrm{~kg} / \mathrm{d}$ on an air-dry basis to cows receiving a mixture (1:1 on a DM basis) of grass silage and red clover silage.

${ }^{3}$ Calculated as milk yield $(\mathrm{kg}) \times[383 \times$ fat $(\%)+242 \times$ protein $(\%)+165.4 \times$ lactose $(\%)+20.7] / 3,140$ (Sjaunja et al., 1990).

${ }^{4}$ Evaluated by 6 trained panelists using a numerical interval scale from 1 (poor) to 5 (excellent).

Furthermore, incremental CO supplementation linearly decreased $(P<0.02)$ milk taste panel score. Treatment had no effect $(P>0.10)$ on butter peroxide and NEFA concentrations over a 12 -wk storage period, which were consistently below $0.15 \mathrm{mmol}$ of $\mathrm{O}_{2} / \mathrm{kg}$ of milk fat and $0.3 \%$, respectively (Supplemental Figures S2 and S3; https://doi.org/10.3168/jds.2016-11438). Butter water content averaged $13.9,13.4,13.8$, and $12.8 \%$ for $0,2,4$, and $6 \% \mathrm{CO}$, respectively (data not presented). Overall, butter flavor was assessed as good or satisfactory for up to $6 \mathrm{wk}$ of storage, but off-flavors were detected thereafter (data not shown).

\section{Milk FA Composition and Secretion}

The effect of $\mathrm{CO}$ supplementation on the major FA in milk fat, 18:1 and 18:2 composition, and FA secretion in milk is shown in Tables 5, 6, and 7, respectively. Treatment effects on the relative proportions of OBCFA, 16:1 and 16:2, and 20:1 isomers in milk fat are reported in Supplemental Tables S2, S3, and S4, respectively (https://doi.org/10.3168/jds.2016-11438). Supplements of CO linearly decreased $(P<0.01)$ the proportions of FA synthesized de novo (4- to 14-carbon and 16:0) in milk fat, with an overall decrease $(P<$ $0.01)$ in total SFA concentration from 58 to $45 \mathrm{~g} / 100 \mathrm{~g}$ of total FA (Table 5).

Inclusion of $\mathrm{CO}$ supplementation had no effect $(P$ $\geq 0.10$ ) on cis-9 18:1, LA, ALA, or total FA output in milk (Table 7). Supplements of CO linearly decreased $(P<0.01)$ the apparent transfer of LA and ALA from the diet into milk (Table 5). Increases in CO linearly enriched $(P<0.01)$ several geometric $\Delta 9,11,15$ 18:3 isomers in milk fat (Table 5) and increased linearly $(P<0.01)$ the relative abundance of $\Delta 8,1518: 2$ and $\Delta 11,15$ 18:2 (Table 6). Inclusion of CO linearly increased $(P<0.01)$ milk fat total CLA content (Table $5)$ and altered the distribution of milk fat CLA isomers characterized as linear increases $(P<0.01)$ in cis-9,trans-11 CLA, trans-8,cis-10 CLA, trans-11,cis-13 CLA, and concominant linear decreases $(P<0.03)$ in trans-9,trans-11 CLA and $\Delta 10,12$ CLA concentrations (Table 6). Furthermore, CO elevated milk fat trans-7,cis-9 CLA, trans-11,trans-13 CLA, and trans12,trans-14 CLA concentrations, reaching a maxium on the 2 and $4 \% \mathrm{CO}$ treatments that declined in response to further oil addition $(P<0.04$ for quadratic effect; Table 6). Incremental amounts of CO linearly increased $(P<0.03)$ milk fat proportions of trans-4 18:1, trans-5 18:1, and trans-11 18:1, but quadratically decreased ( $P$ $<0.01)$ trans-10 18:1 concentration (Table 6). Overall, CO supplementation increased linearly $(P<0.01)$ total trans FA concentration in milk fat (Table 5) and the secretion of trans FA in milk (Table 7), without altering $(P>0.10)$ the relative proportions of $18: 0$ in milk fat (Table 5) or secretion of 18:0 in milk (Table 7).

Supplements of CO altered milk fat OBCFA concentrations (Supplemental Table S2; https://doi. org/10.3168/jds.2016-11438), changes characterized by linear decreases $(P<0.05)$ in milk fat concentration of numerous 5- to 25-carbon OBCFA. Inclusion of $\mathrm{CO}$ altered the relative distribution of 16-carbon FA in milk 
fat, resulting in linear decreases $(P<0.04)$ in cis 16:1 ( $\Delta 9$ to 13$)$ and trans-13 $16: 1$ and linear increases $(P<$ $0.01)$ in trans-9 $16: 1$, trans-9,trans-12 $16: 2$, and $\Delta 9,13$ 16:2 concentrations. (Supplemental Table S3; https:// doi.org/10.3168/jds.2016-11438).

Incremental amounts of $\mathrm{CO}$ linearly increased $(P<$ 0.02) milk fat cis 20:1 ( $\Delta 11$ and 13$)$ and trans $20: 1$ $(\Delta 6+7+8$ and 11$)$ concentrations (Supplemental Table S4; https://doi.org/10.3168/jds.2016-11438), but had no major effect $(P>0.07)$ on the daily yields of $20: 0$ and cis-9 20:1 (Table 7). Inclusion of CO also elevated $(P<0.01)$ the proportion of cis-13 22:1 in milk fat in a linear manner (Table 5). Camelina oil supplementation altered the relative abundance of 20- to 22-carbon n-3 PUFA, increasing linearly $(P<0.01)$ cis-11, cis14,cis-17 20:3 and cis-13,cis-16,cis-19 22:3 and decreasing linearly $(P<0.03)$ cis-5, cis-8, cis-11,cis-14,cis-17 20:5 (eicosapentaenoic acid, EPA), cis-7,cis-10,cis13,cis-16,cis-19 22:5, and cis-4,cis-7,cis-10,cis-13,cis16, cis-19 22:6 (docosahexaenoic acid, DHA) concentrations. Furthermore, inclusion of CO decreased linearly $(P<0.05)$ several product to substrate concentration ratios for stearoyl-CoA desaturase (SCD1) in milk fat (Table 5).

\section{DISCUSSION}

\section{DMI}

Supplements of plant oils and oilseeds typically decrease DMI when included in amounts above $50 \mathrm{~g}$ of oil $/ \mathrm{kg}$ of $\mathrm{DM}$, a response often attributed to the adverse effect of unsaturated FA on rumen microbial communities, lowered ruminal OM and NDF digestion (Allen, 2000; Lock and Shingfield, 2004), and an increase in gut peptide secretion (Litherland et al., 2005; Relling and Reynolds, 2007). By design, incremental inclusion of $\mathrm{CO}$ in concentrate supplements increased the FA content of the total diet from 33 to $60 \mathrm{~g} / \mathrm{kg}$ of DM. Increases in CO decreased silage and total DMI by 27 and $18 \%$, respectively, in the absence of changes in total-tract NDF digestibility. The magnitude of decreases in intake were higher compared with a recent report of a $12 \%$ decrease in DMI in response to inclusion of $60 \mathrm{~g}$ of $\mathrm{CO} / \mathrm{kg}$ of DM that increased the FA content of a TMR based on grass silage from 22 to 77 $\mathrm{g} / \mathrm{kg}$ of DM (Bayat et al., 2015). However, both the proportion of concentrate in diet DM (from 50 to 55\%) and apparent total-tract OM digestibility (from 74 to $75 \%$ ) were similar in this and the earlier report (50 and from 69 to $72 \%$, respectively; Bayat et al., 2015). The larger decrease in DMI to $\mathrm{CO}$ in the present experiment might have been related to the inclusion in concentrates fed separately at specified time points, leading to a more sudden release of unsaturated FA in the rumen compared with adding CO as part of a TMR (Bayat et al., 2015). Decreases in DMI to linseed oil supplementation (from 4 to $6 \%$ of diet DM) have been shown to be much more pronounced when concentrates were fed separately ( $-26 \%$; Chilliard et al., 2009), rather than as part of a TMR (from no change to $-9 \%$; Bell et al., 2006; Benchaar et al., 2015).

There are relatively few reports on the effect of $\mathrm{CO}$ on DMI, but indirect comparisons do not provide substantive evidence to suggest that $\mathrm{CO}$ has more adverse effects on intake (Hurtaud and Peyraud, 2007; Halmemies-Beauchet-Filleau et al., 2011; Bayat et al., 2015) compared with other plant oils of similar FA composition (Bell et al., 2006; Chilliard et al., 2009). Nevertheless, camelina expeller or meal has been reported to result in marginally greater decreases in DMI compared with provision of the same amount of lipid as camelina oil (Halmemies-Beauchet-Filleau et al., 2011) or whole seeds (Hurtaud and Peyraud, 2007). Furthermore, the intake of diets based on RCS has been shown to be unaffected or marginally decreased in response to plant oil (rapeseed, sunflower seed, camelina seed, or linseed) supplements (Halmemies-Beauchet-Filleau et al., 2011; Benchaar et al., 2015), with the implication that feeding diets containing a mixture of grass silage and RCS is not the sole explanation for the relatively high decrease in DMI on the $6 \%$ CO treatment.

\section{Rumen Fermentation and Nutrient Digestibility}

Supplements of PUFA typically modify rumen fermentation, characterized by a shift toward propionate at the expense of acetate, butyrate, or both lipogenic VFA (Ueda et al., 2003; Hurtaud and Peyraud, 2007; Shingfield et al., 2008a). Changes in molar VFA proportions to plant oils may be related to the toxic effects of LA and ALA on specific cellulolytic and butyrate-producing bacteria (Maia et al., 2007; Yang et al., 2009). There were no indications in this or an earlier study (Bayat et al., 2015) to suggest that CO alters rumen fermentation characteristics or depresses fiber digestion. However, the associated decrease in DMI in response to CO supplements may have resulted in a higher ruminal retention time, compensating for possible adverse effects of PUFA on NDF digestion. Soluble Ca may alleviate possible negative effects of unsaturated FA on fiber digestion due to formation of Ca salts (Doreau and Chilliard, 1997). Conversely, a shortage of Ca may compromise the attachment and colonization of cellulolytic bacteria to feed particles in the rumen (Doreau and Chilliard, 1997). Typically, Ca concentrations are higher in RCS compared with grass silage or maize silage (Luke, 2015). 
Table 5. Effect of incremental amounts of camelina oil on milk fatty acid composition

\begin{tabular}{|c|c|c|c|c|c|c|c|c|}
\hline \multirow[b]{2}{*}{ Fatty acid, g/100 g } & \multicolumn{4}{|c|}{ Camelina oil in concentrate, $\%$} & \multirow[b]{2}{*}{$\mathrm{SEM}^{1}$} & \multicolumn{3}{|c|}{$P$-value ${ }^{2}$} \\
\hline & 0 & 2 & 4 & 6 & & $\mathrm{~L}$ & $\mathrm{Q}$ & $\mathrm{C}$ \\
\hline $4: 0$ & 2.87 & 2.88 & 2.92 & 2.61 & 0.112 & 0.132 & 0.142 & 0.433 \\
\hline $6: 0$ & 1.69 & 1.67 & 1.62 & 1.45 & 0.076 & 0.028 & 0.285 & 0.794 \\
\hline $8: 0$ & 1.05 & 1.00 & 0.92 & 0.84 & 0.056 & 0.004 & 0.694 & 0.894 \\
\hline 10:0 & 2.40 & 2.23 & 2.00 & 1.82 & 0.150 & 0.002 & 0.967 & 0.769 \\
\hline cis-9 10:1 & 0.26 & 0.24 & 0.22 & 0.17 & 0.017 & 0.001 & 0.189 & 0.566 \\
\hline $12: 0$ & 3.01 & 2.76 & 2.47 & 2.20 & 0.161 & $<0.001$ & 0.932 & 0.922 \\
\hline cis-9 12:1 & 0.08 & 0.07 & 0.06 & 0.05 & 0.005 & $<0.001$ & 0.127 & 0.176 \\
\hline trans-9 12:1 & 0.08 & 0.07 & 0.07 & 0.05 & 0.005 & $<0.001$ & 0.148 & 0.488 \\
\hline $14: 0$ & 11.6 & 10.7 & 9.89 & 8.94 & 0.430 & $<0.001$ & 0.980 & 0.741 \\
\hline cis-9 14:1 & 1.31 & 1.19 & 1.11 & 0.81 & 0.096 & $<0.001$ & 0.053 & 0.230 \\
\hline cis-13 14:1 & 0.03 & 0.02 & 0.02 & 0.01 & 0.003 & 0.006 & 0.796 & 0.688 \\
\hline trans-9 14:1 & 0.02 & 0.02 & 0.02 & 0.01 & 0.001 & $<0.001$ & 0.138 & 0.069 \\
\hline $16: 0$ & 26.2 & 25.3 & 23.1 & 20.1 & 1.38 & 0.001 & 0.262 & 0.917 \\
\hline$\Sigma$ cis $16: 1$ & 2.13 & 2.00 & 1.82 & 1.45 & 0.117 & $<0.001$ & 0.069 & 0.553 \\
\hline$\Sigma$ trans $16: 1$ & 0.82 & 0.96 & 0.99 & 1.05 & 0.060 & 0.007 & 0.427 & 0.503 \\
\hline$\Sigma 16: 1$ & 2.94 & 2.96 & 2.82 & 2.52 & 0.129 & 0.004 & 0.084 & 0.964 \\
\hline 18:0 & 4.73 & 3.75 & 4.33 & 3.78 & 0.523 & 0.265 & 0.620 & 0.182 \\
\hline 9-O-18:0 & 0.02 & 0.02 & 0.02 & 0.05 & 0.007 & 0.006 & 0.076 & 0.243 \\
\hline 10-O-18:0 & 0.05 & 0.07 & 0.06 & 0.20 & 0.029 & 0.004 & 0.057 & 0.188 \\
\hline 13-O-18:0 & 0.01 & 0.01 & 0.01 & 0.02 & 0.001 & 0.005 & 0.412 & 0.294 \\
\hline 15-O-18:0 & 0.01 & 0.01 & 0.01 & 0.01 & 0.001 & 0.962 & 0.825 & 0.802 \\
\hline$\Sigma$ cis $18: 1$ & 12.7 & 11.3 & 12.7 & 12.2 & 0.75 & 0.991 & 0.419 & 0.067 \\
\hline$\Sigma$ trans $18: 1$ & 11.7 & 13.9 & 14.5 & 15.9 & 0.67 & $<0.001$ & 0.434 & 0.280 \\
\hline$\Sigma 18: 1$ & 24.4 & 25.2 & 27.2 & 28.1 & 1.06 & 0.002 & 0.907 & 0.454 \\
\hline$\sum 18: 2^{3}$ & 5.10 & 6.37 & 6.53 & 9.35 & 0.679 & $<0.001$ & 0.242 & 0.203 \\
\hline$\Sigma$ CLA & 2.92 & 3.68 & 3.83 & 4.60 & 0.415 & 0.008 & 0.983 & 0.457 \\
\hline cis- 6 ,cis- 9, cis-12 18:3 & 0.02 & 0.02 & 0.02 & 0.01 & 0.002 & 0.023 & 0.753 & 0.385 \\
\hline cis-9,cis-12,cis-15 18:3 & 0.66 & 0.63 & 0.64 & 0.64 & 0.049 & 0.843 & 0.752 & 0.718 \\
\hline cis-9,trans-11, cis-15 18:3 & 0.05 & 0.06 & 0.06 & 0.07 & 0.005 & 0.005 & 0.992 & 0.662 \\
\hline$\Delta 9,11,1518: 3^{4}$ & 0.18 & 0.26 & 0.29 & 0.41 & 0.032 & $<0.001$ & 0.586 & 0.295 \\
\hline$\Delta 9,11,1518: 3$ & 0.01 & 0.01 & 0.01 & 0.02 & 0.001 & $<0.001$ & 0.483 & 0.545 \\
\hline$\Delta 9,11,1518: 3$ & 0.01 & 0.01 & 0.01 & 0.01 & 0.001 & 0.233 & 0.956 & 0.773 \\
\hline 20:0 & 0.36 & 0.35 & 0.44 & 0.46 & 0.044 & 0.026 & 0.623 & 0.286 \\
\hline$\Sigma$ cis $20: 1$ & 1.96 & 2.72 & 3.17 & 4.61 & 0.371 & $<0.001$ & 0.323 & 0.392 \\
\hline$\Sigma$ trans $20: 1$ & 0.34 & 0.37 & 0.46 & 0.43 & 0.054 & 0.116 & 0.464 & 0.332 \\
\hline$\Sigma 20: 1$ & 2.31 & 3.10 & 3.65 & 5.04 & 0.345 & $<0.001$ & 0.337 & 0.445 \\
\hline cis-11,cis-14 20:2 & 0.17 & 0.24 & 0.26 & 0.43 & 0.040 & $<0.001$ & 0.220 & 0.215 \\
\hline trans-9,trans -15 20:2 & 0.01 & 0.01 & 0.02 & 0.01 & 0.002 & 0.953 & 0.434 & 0.217 \\
\hline$\Delta 9,1620: 2$ & 0.03 & 0.04 & 0.05 & 0.05 & 0.003 & $<0.001$ & 0.301 & 0.437 \\
\hline cis- 8, cis-11,cis-14 20:3 & 0.05 & 0.04 & 0.04 & 0.04 & 0.006 & 0.006 & 0.215 & 0.920 \\
\hline cis-11,cis-14,cis-17 20:3 & 0.06 & 0.09 & 0.10 & 0.19 & 0.020 & $<0.001$ & 0.127 & 0.188 \\
\hline cis-5,cis-8,cis-11,cis-14 20:4 & 0.050 & 0.048 & 0.046 & 0.047 & 0.0035 & 0.070 & 0.345 & 0.919 \\
\hline cis-8,cis-11,cis-14,cis-17 20:4 & 0.05 & 0.05 & 0.05 & 0.04 & 0.005 & 0.015 & 0.593 & 0.030 \\
\hline$\Delta 5,11,14,1720: 4$ & 0.01 & 0.02 & 0.02 & 0.03 & 0.003 & 0.002 & 0.520 & 0.519 \\
\hline cis-5, cis-8,cis-11,cis-14,cis-17 20:5 & 0.04 & 0.03 & 0.03 & 0.03 & 0.003 & 0.003 & 0.368 & 0.459 \\
\hline $22: 0$ & 0.09 & 0.09 & 0.08 & 0.08 & 0.005 & 0.260 & 0.991 & 0.557 \\
\hline cis-9 22:1 & 0.020 & 0.016 & 0.018 & 0.016 & 0.0011 & 0.126 & 0.743 & 0.071 \\
\hline cis-13 22:1 & 0.24 & 0.33 & 0.38 & 0.53 & 0.036 & $<0.001$ & 0.348 & 0.391 \\
\hline cis-15 22:1 & 0.03 & 0.04 & 0.04 & 0.04 & 0.004 & 0.050 & 0.173 & 0.166 \\
\hline cis-13,cis-16 22:2 & 0.02 & 0.03 & 0.03 & 0.03 & 0.002 & $<0.001$ & 0.470 & 0.332 \\
\hline cis-13,cis-16,cis-19 22:3 & 0.03 & 0.05 & 0.05 & 0.08 & 0.006 & $<0.001$ & 0.489 & 0.241 \\
\hline cis-9,cis-12,cis-15,cis-18 22:4 & 0.01 & 0.01 & 0.01 & 0.01 & 0.001 & 0.152 & 0.756 & 0.887 \\
\hline cis-4,cis-7,cis-10,cis-13,cis-16 22:5 & 0.01 & 0.01 & 0.01 & 0.02 & 0.003 & 0.028 & 0.058 & 0.389 \\
\hline cis- 7, cis-10,cis-13,cis-16,cis-19 22:5 & 0.05 & 0.04 & 0.04 & 0.04 & 0.006 & 0.025 & 0.208 & 0.771 \\
\hline cis-4,cis-7,cis-10,cis-13,cis-16,cis-19 22:6 & 0.004 & 0.004 & 0.003 & 0.003 & 0.0004 & 0.017 & 0.822 & 0.890 \\
\hline 24:0 & 0.04 & 0.03 & 0.03 & 0.03 & 0.001 & $<0.001$ & 0.059 & 0.073 \\
\hline cis-15 24:1 & 0.04 & 0.04 & 0.04 & 0.05 & 0.003 & 0.012 & 0.621 & 0.841 \\
\hline 26:0 & 0.03 & 0.03 & 0.03 & 0.03 & 0.004 & 0.172 & 0.227 & 0.513 \\
\hline cis-17 26:1 & 0.004 & 0.004 & 0.004 & 0.004 & 0.0004 & 0.680 & 0.841 & 0.691 \\
\hline $28: 0$ & 0.006 & 0.006 & 0.006 & 0.005 & 0.0005 & 0.166 & 0.755 & 0.733 \\
\hline$\Sigma$ Unidentified & 0.29 & 0.29 & 0.28 & 0.22 & 0.025 & 0.035 & 0.114 & 0.735 \\
\hline
\end{tabular}


Table 5 (Continued). Effect of incremental amounts of camelina oil on milk fatty acid composition

\begin{tabular}{|c|c|c|c|c|c|c|c|c|}
\hline \multirow[b]{2}{*}{ Fatty acid, g/100 g } & \multicolumn{4}{|c|}{ Camelina oil in concentrate, $\%$} & \multirow[b]{2}{*}{$\mathrm{SEM}^{1}$} & \multicolumn{3}{|c|}{$P$-value ${ }^{2}$} \\
\hline & 0 & 2 & 4 & 6 & & $\mathrm{~L}$ & $\mathrm{Q}$ & $\mathrm{C}$ \\
\hline \multicolumn{9}{|l|}{ Summary } \\
\hline$\sum 4$ - to 14 -carbon & 24.8 & 23.1 & 21.6 & 19.2 & 0.89 & $<0.001$ & 0.518 & 0.714 \\
\hline$\Sigma$ Trans fatty acids & 19.5 & 24.1 & 25.2 & 30.2 & 1.53 & $<0.001$ & 0.868 & 0.234 \\
\hline$\Sigma$ SFA & 57.7 & 53.9 & 50.9 & 45.3 & 2.14 & $<0.001$ & 0.595 & 0.672 \\
\hline$\Sigma$ MUFA & 32.3 & 33.8 & 36.2 & 37.9 & 1.23 & $<0.001$ & 0.887 & 0.698 \\
\hline cis-9 10:1/10:0 & 0.110 & 0.108 & 0.112 & 0.095 & 0.0071 & 0.031 & 0.073 & 0.126 \\
\hline cis-9 12:1/12:0 & 0.027 & 0.025 & 0.026 & 0.022 & 0.0015 & 0.002 & 0.086 & 0.063 \\
\hline cis-9 14:1/14:0 & 0.115 & 0.113 & 0.113 & 0.090 & 0.0100 & 0.004 & 0.034 & 0.208 \\
\hline cis-9 16:1/16:0 & 0.074 & 0.072 & 0.072 & 0.067 & 0.0038 & 0.116 & 0.648 & 0.602 \\
\hline cis-9 18:1/18:0 & 2.361 & 2.581 & 2.539 & 3.002 & 0.2820 & 0.100 & 0.596 & 0.458 \\
\hline cis-9,trans-11 CLA/trans-11 18:1 & 0.487 & 0.453 & 0.461 & 0.414 & 0.0220 & 0.032 & 0.725 & 0.287 \\
\hline cis-9 20:1/20:0 & 1.098 & 1.032 & 1.049 & 0.912 & 0.0544 & 0.018 & 0.427 & 0.241 \\
\hline \multicolumn{9}{|l|}{ Transfer from the diet in milk, $\%$} \\
\hline
\end{tabular}

${ }^{1}$ SEM for the $4 \%$ camelina oil treatment. SEM for 0,2 , and $6 \%$ camelina oil treatments are proportionately $0.954,0.921$, and 0.955 of the reported value, respectively.

${ }^{2}$ Significance of linear (L), quadratic (Q), and cubic (C) components of the response to incremental inclusion of camelina oil in concentrates fed at $12 \mathrm{~kg} / \mathrm{d}$ on an air-dry basis to cows receiving a mixture (1:1 on a DM basis) of grass silage and red clover silage.

${ }^{3}$ Does not include isomers of CLA.

${ }^{4}$ Co-elutes with $\Delta 13,17$ 20:2.

Increases in $\mathrm{CO}$ supplementation were associated with an increase in total-tract apparent crude fat digestibility from 71 to $81 \%$, but the increases from 4 to $6 \%$ $\mathrm{CO}$ were marginal. Such findings are consistent with a finite capacity for FA absorption in the small intestine of lactating cows (Schmidely et al., 2008) that may be related to the saturation of 18:0 intestinal absorption at high postruminal flows (Glasser et al., 2008). In cows fed grass silage or RCS diets, 18:0 is typically the major FA leaving the rumen (Shingfield et al., 2008a, 2012; Halmemies-Beauchet-Filleau et al., 2013b).

\section{Plasma Metabolites}

Incremental CO supplementation increased plasma NEFA and lowered acetic acid concentration and led to numerical decreases in plasma glucose and insulin concentrations, changes that can be explained by the decreases in DMI. Such responses suggest that a higher proportion of energy requirements for milk production was met through the mobilization of body energy reserves consistent with the loss of BCS at high $\mathrm{CO}$ inclusion rates. Increases in FA supply at the intestine may also elevate circulating NEFA concentrations (Gagliostro et al., 1991; Drackley et al., 1992), due to the release of FA into the plasma NEFA pool following the action of lipoprotein lipase on triacylglycerols transported in chylomicrons. Earlier studies have reported that camelina seeds and meal lower plasma glucose concentration and DMI in lactating cows (Hurtaud and Peyraud, 2007).

\section{Milk Production and Sensory Quality}

Incremental $\mathrm{CO}$ supplementation progressively decreased milk and lactose yields, reflecting the decrease in DMI. No direct measurements of energy status were made, but inclusion of $\mathrm{CO}$ in concentrates was associated with numerical decreases in calculated ME balance and plasma glucose concentrations consistent with changes in BCS. A linear decline in milk protein yield and milk protein and urea concentrations in response to $\mathrm{CO}$ can be attributed to lowered $\mathrm{ME}$ and nitrogen intakes due to the decrease in both total DMI and concentrate CP content. Milk protein concentration is often decreased by lipid supplementation due to the effects on energy intake and limitations in glucose supply and microbial protein synthesis (Lock and Shingfield, 2004). In the present study, milk protein concentration was low across all diets (29 to $31 \mathrm{~g} / \mathrm{kg}$ of milk) compared with typical values of 34 to $36 \mathrm{~g} / \mathrm{kg}$ in milk from Finnish Ayrshire cows in mid lactation (Korhonen at al., 2002; Halmemies-Beauchet-Filleau et al., 2014). Earlier studies have shown that camelina expeller or meal lowers milk protein concentrations (Hurtaud and Peyraud, 2007; Halmemies-Beauchet-Filleau et al., 2011). In addition to the effects attributable to increases in lipid intake, the low milk protein concentration across all 
Table 6. Effect of incremental amounts of camelina oil on milk 18:1 and 18:2 composition

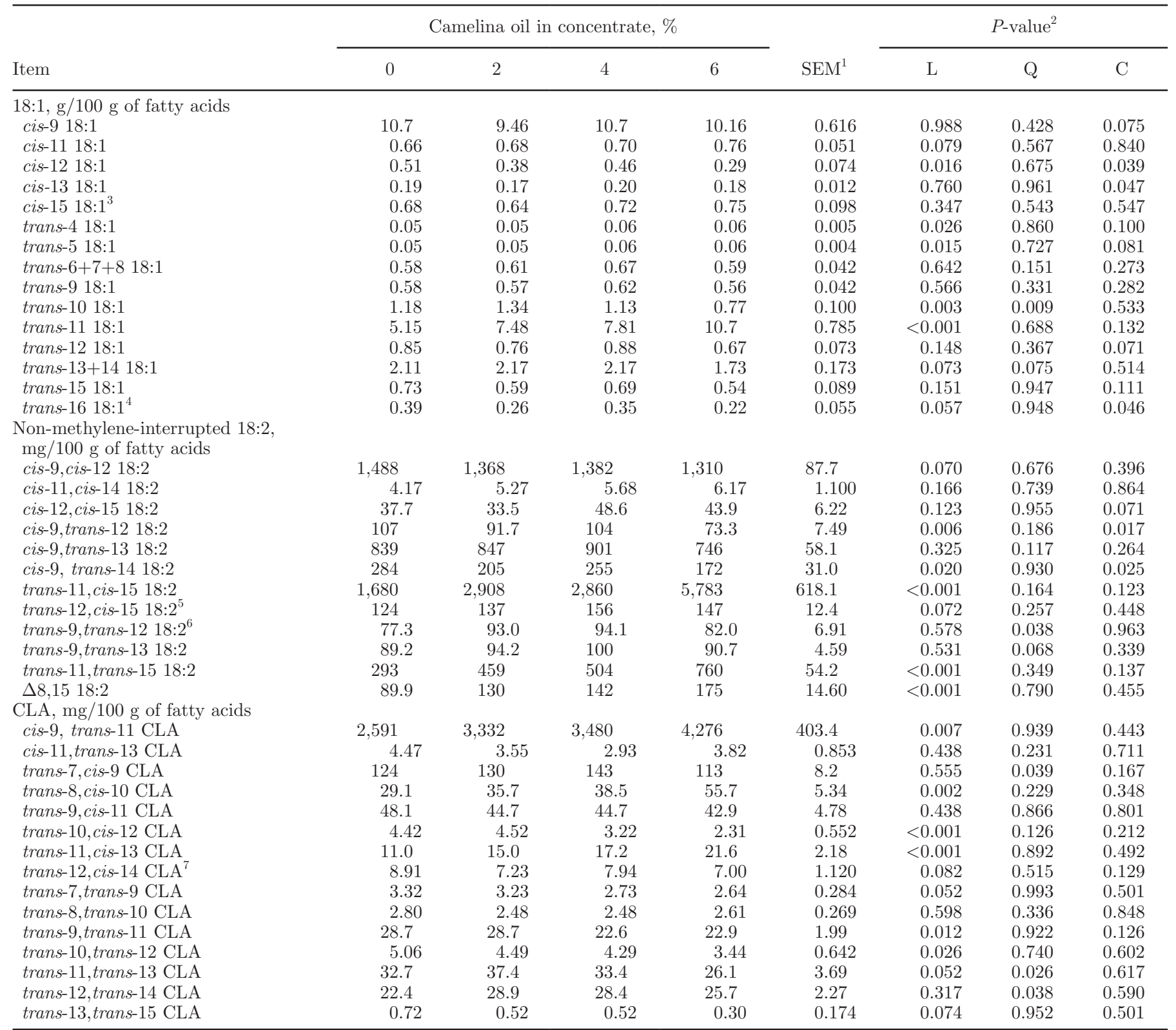

${ }^{1}$ SEM for the $4 \%$ camelina oil treatment. SEM for 0,2 , and $6 \%$ camelina oil treatments are proportionately $0.954,0.921$, and 0.955 of the reported value, respectively.

${ }^{2}$ Significance of linear (L), quadratic (Q), and cubic (C) components of the response to incremental inclusion of camelina oil in concentrates fed at $12 \mathrm{~kg} / \mathrm{d}$ on an air-dry basis to cows receiving a mixture (1:1 on a DM basis) of grass silage and red clover silage.

${ }^{3}$ Co-elutes with 19:0.

${ }^{4}$ Co-elutes with cis-14 18:1.

${ }^{5}$ Co-elutes with cis-11 19:1.

${ }^{6}$ Co-elutes with cis-11,trans-15 18:2.

${ }^{7}$ Co-elutes with cis-13,trans-15 CLA.

treatments may be explained by the lower histidine concentration of camelina protein compared with soybean or rapeseed protein (Zubr, 2003b). Histidine is considered the first-limiting AA for milk and protein synthesis in grass silage- and cereal-based diets (Vanhatalo et al., 1999). Rumen ammonia concentrations did not differ due to treatment, but varied between 4.37 and $10.9 \mathrm{mmol} / \mathrm{L}$ across sampling times (data not 
Table 7. Effect of incremental amounts of camelina oil on milk fatty acid secretion

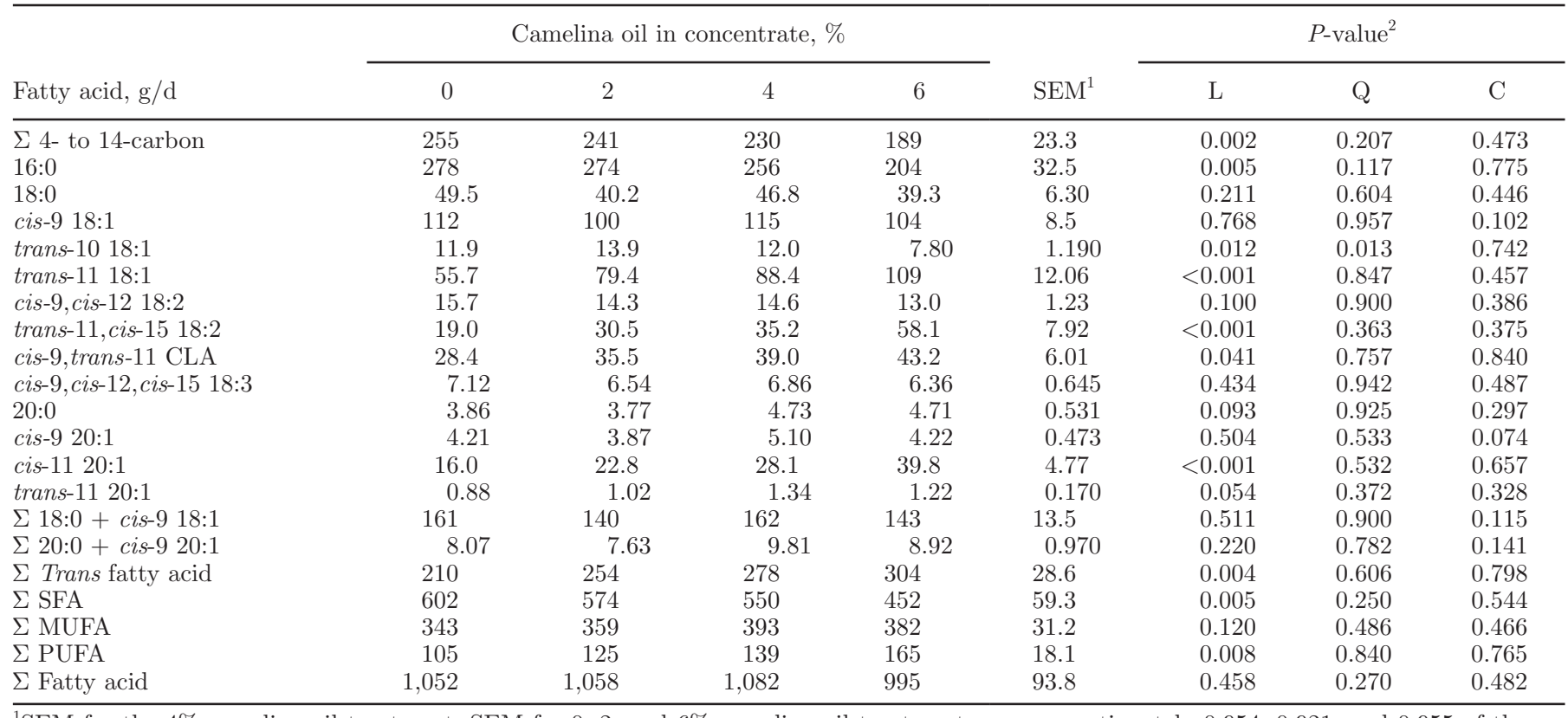

${ }^{1}$ SEM for the $4 \%$ camelina oil treatment. SEM for 0,2 , and $6 \%$ camelina oil treatments are proportionately $0.954,0.921$, and 0.955 of the reported value, respectively.

${ }^{2}$ Significance of linear (L), quadratic (Q), and cubic (C) components of the response to incremental inclusion of camelina oil in concentrates fed at $12 \mathrm{~kg} / \mathrm{d}$ on an air-dry basis to cows receiving a mixture (1:1 on a DM basis) of grass silage and red clover silage.

shown), averaging $8.58 \mathrm{mmol} / \mathrm{L}$, which suggests that there was sufficient RDP on all treatments to support microbial growth (Schwab et al., 2005).

Even though CO resulted in dose-dependent changes in milk FA composition, milk fat secretion was unaffected. Feeding low fiber-high starch diets, rations containing relatively high amounts of PUFA or high concentrate-high oil diets often decrease the milk fat content in lactating cows, a phenomenon referred to as diet-induced milk fat depression (MFD; Shingfield et al., 2010). Earlier reports have shown that dietary supplements of camelina seeds or CO depress milk fat yield when fed in relatively high amounts (Hurtaud and Peyraud, 2007; Mihhejev et al., 2007; Bayat et al., 2015). The relative proportion of concentrate in diet DM was similar in the present (from 50 to $55 \%$ ) and earlier experiments ( $42 \%$ in Hurtaud and Peyraud, 2007; 50\% in Bayat et al., 2015), but forage species and composition differed. Previous reports have examined responses in cows fed diets based on corn silage (Hurtaud and Peyraud, 2007) or grass silage as the sole forage (Mihhejev et al., 2007; Bayat et al., 2015), wherein decreases in milk fat secretion have been accompanied by enrichment of intermediates formed by the trans-10 biohydrogenation pathway (Shingfield et al., 2010). In contrast, the relative abundance of these intermediates in milk fat was decreased by $\mathrm{CO}$ treat- ments, possibly due to the inclusion of RCS in the diet that has an inherently higher buffering capacity (Koivunen et al., 2015), which may have prevented shifts in biohydrogenation pathways despite the increase in PUFA availability in the rumen. Nevertheless, this does not appear to be the sole explanation as an earlier study showed that camelina expeller, and to a lesser extent $\mathrm{CO}$, slightly increased milk fat trans-10 18:1 and trans-10,cis-12 CLA concentrations when RCS was the only forage in the diet (HalmemiesBeauchet-Filleau et al., 2011). In the present experiment, $\mathrm{CO}$ elevated milk fat concentration due to a decrease in milk yield rather than higher fat synthesis in the mammary gland.

Incremental amounts of $\mathrm{CO}$ in concentrates resulted in a progressive decrease in the secretion in milk of FA synthesized de novo in the mammary gland, that may, at least in part, be explained by a decrease in the mammary supply of acetate, as inferred from the decline in plasma acetate concentrations. Despite the decrease in FA de novo synthesis in the mammary gland, $\mathrm{CO}$ treatments did not induce MFD. Measurements of milk FA output indicated that the decrease in short- and medium-chain FA to $\mathrm{CO}$ treatments was compensated for by higher uptake and incorporation of preformed FA. During MFD, the secretion of all FA is depressed, but the decrease is proportionately greater for FA 
synthesized de novo (Shingfield et al., 2010). Several theories have been proposed to explain diet-induced MFD that include (1) a decrease in the supply of acetate and BHB for FA synthesis de novo, (2) elevated insulin secretion causing the partitioning of FA toward adipose tissue at the expense of mammary gland, or (3) direct inhibition of mammary lipogenesis by specific trans FA intermediates formed by alterations in the major biohydrogenation pathways in the rumen (Shingfield et al., 2010). Experimental treatments had no effect on milk fat output consistent with numerical decreases in plasma insulin concentrations and an absence of shifts in ruminal biohydrogenation favoring the formation of trans-10-containing intermediates, including trans-10,cis-12 CLA known to inhibit milk fat synthesis in lactating cows (Baumgard et al., 2001). Typically, supplementing fiber-rich diets with plant oils increases the output of long-chain FA in milk, whereas inclusion of plant oils in starch-rich diets causing MFD has no effect or decreases the secretion of $\geq 16$-carbon FA (Shingfield et al., 2010).

Incremental CO supplementation compromised the sensory attributes of milk that may reflect the alterations in milk fat composition. There is increasing evidence that FA interact with human taste cells, playing important roles in gustation, olfaction, and somatosensation, factors that contribute to the overall flavor perception of foods (Tucker et al., 2014). Furthermore, NEFA receptors may react differently or have a different affinity for FA varying in chain length, degree of saturation, or both (Tucker et al., 2014). Relative to sunflower seed oil or rapeseed oil, dietary supplements of camelina expeller result in greater enrichment of PUFA and trans FA, lower milk fat SFA concentration, and a numerical decrease in taste panel score, changes that were not associated with changes in milk fat peroxides (Halmemies-Beauchet-Filleau et al., 2011) formed during the initial stages of lipid peroxidation (Halliwell and Chirico, 1993). In butter, oxidative off-flavors become detectable at $0.6 \mathrm{mmol}$ of $\mathrm{O}_{2} / \mathrm{kg}$ and an upper threshold of $0.4 \mathrm{mmol}$ of $\mathrm{O}_{2} / \mathrm{kg}$ is recommended (Early, 1998). In the present study, the peroxide value of experimental butters did not exceed $0.3 \mathrm{mmol}$ of $\mathrm{O}_{2} / \mathrm{kg}$. Camelina oil contains $\alpha$ - and $\gamma$-tocopherols $(28.1$ and $742 \mathrm{ppm}$, respectively; Zubr and Matthäus, 2002), which may account for the stable peroxide concentrations during prolonged storage of butter despite a higher concentration of PUFA in milk fat from cows fed CO treatments. Milk $\alpha$ - and $\gamma$-tocopherol concentrations can be modified by diet (Kanno et al., 1968; Havemose et al., 2004), but the efficiency of transfer of $\alpha$-tocopherol from the diet into milk gradually declines at high inclusion rates (Weiss and Wyatt, 2003).

\section{Milk FA Composition and Secretion}

$\boldsymbol{S F A}$. Bovine milk fat typically contains SFA between 67 and $75 \mathrm{~g} / 100 \mathrm{~g}$ of total FA (Lock and Shingfield, 2004; Lindmark-Månsson, 2008). Inclusion of CO in concentrate supplements progressively decreased milk fat SFA concentration from 58 to $45 \mathrm{~g} / 100 \mathrm{~g}$ of total FA due to decreased secretion of 4- to 16-carbon FA. All 4- to 12-carbon FA, most of 14:0, and a high proportion of 16:0 in milk fat are synthesized de novo in the bovine mammary gland using acetate and BHB as substrates (Chilliard et al., 2000; Halmemies-Beauchet-Filleau et al., 2013a; Shingfield et al., 2013). Incremental CO supplementation had no major effect on plasma BHB concentration, but the circulating level of acetic acid was decreased by $27 \%$. The mammary gland extracts from 51 to $77 \%$ of acetic acid in arterial blood (Bickerstaffe et al., 1974; Korhonen et al., 2002) and there is a direct positive relationship between acetic acid in plasma and mammary uptake (Cant et al., 1993). It is therefore possible that a decrease in the supply of short-chain FA precursors for mammary FA synthesis may, at least in part, explain the reduced secretion of de novo SFA in response to CO treatments.

Increases in the availability of 16-carbon or longer chain FA are known to inhibit mammary acetyl-CoA carboxylase activity (Chilliard et al., 2000) that may also have contributed to lowered de novo FA synthesis in response to CO. Trans-10, cis-12 CLA is known to inhibit milk fat synthesis in cows (Baumgard et al., 2001), and some evidence suggests that other biohydrogenation intermediates, including trans-10 18:1 and trans-9,cis-11 CLA, may also exert antilipogenic effects (Shingfield et al., 2010). A lack of increase in the abundance of these FA in milk fat tends to suggest that these had no major role in contributing to decreases in mammary de novo FA synthesis in cows fed $\mathrm{CO}$ in the present study. Overall, CO supplementation decreased milk fat total SFA by 0.03 percentage units per gram of additional FA intake, which is within the range of responses (from 0.02 to 0.04) reported for rapeseed, sunflower seed, or linseed oil (Chilliard et al., 2009; Halmemies-Beauchet-Filleau et al., 2011). On all diets, milk fat SFA concentrations were much lower than typical for cows fed diets based on grass silage or RCS or a mixture of both forages (HalmemiesBeauchet-Filleau et al., 2013a, 2014), which appears to be explained by the use of camelina expeller as a protein source in concentrate supplements. Camelina expeller is relatively rich in lipid (Mihhejev et al., 2007; Halmemies-Beauchet-Filleau et al., 2011) and is known to decrease milk SFA concentrations (Mihhejev et al., 2007; Halmemies-Beauchet-Filleau et al., 2011). 
$\boldsymbol{L} \boldsymbol{A}$ and $\boldsymbol{A} \boldsymbol{L} \boldsymbol{A}$. Despite being relatively rich in PUFA, incremental $\mathrm{CO}$ supplementation did not increase LA and ALA secretion in milk. A lack of enrichment in milk can be explained by extensive biohydrogenation of dietary PUFA in the rumen as indicated by the progressive decrease in the efficiency of LA and ALA transfer from the diet into milk in response to incremental inclusion of $\mathrm{CO}$ in concentrates. These findings are consistent with previous reports indicating that $\mathrm{CO}$ supplementation in lactating cows is not an effective means for enriching LA and ALA in milk (Bayat et al., 2015).

Milk 18-Carbon Biohydrogenation Intermediates and 18:0 Concentrations. Inclusion of CO linearly increased the abundance of FA in milk fat formed during the incomplete biohydrogenation of cis-9 18:1, LA, and ALA in the rumen, with a relatively high enrichment of intermediates synthesized by the trans-11 pathway, including cis-9,trans-11,cis-15 18:3, trans11,cis-15 18:2, cis-9,trans-11 CLA, and trans-11 18:1 (Shingfield et al., 2010). Even though concentrations of cis-9,trans-11 CLA were increased by CO, the majority of cis-9,trans-11 CLA in milk is known to originate from the desaturation of trans-11 18:1 in the mammary glands (Mosley et al., 2006; Halmemies-Beauchet-Filleau et al., 2013a). Consistent with a product-substrate for SCD1, CO elevated milk fat cis-9,trans-11 CLA concentrations from 2.6 to $4.3 \mathrm{~g} / 100 \mathrm{~g}$ of total FA, which was accompanied by increases in milk trans-11 18:1 concentrations from 5.2 to $11 \mathrm{~g} / 100 \mathrm{~g}$ of total FA. Earlier studies have reported cis-9,trans-11 CLA and trans-11 18:1 concentrations in milk of 5.0 and 8.3 $\mathrm{g} / 100 \mathrm{~g}$ of total FA in milk from cows fed camelina expeller (Mihhejev et al., 2007). In the present study, the increase in milk fat cis-9,trans-11 CLA to CO (0.0046 percentage unit per $\mathrm{g}$ of additional FA intake) was several-fold higher than reported previously for $\mathrm{CO}$ (from 0.00047 to 0.00054; Halmemies-Beauchet-Filleau et al., 2011; Bayat et al., 2015) or rapeseed, sunflower seed, or linseed oil (from 0 to 0.00084; Rego et al., 2009; Halmemies-Beauchet-Filleau et al., 2011), but similar to the responses to camelina meal or camelina expeller (from 0.0033 to 0.0086; Hurtaud and Peyraud, 2007; Mihhejev et al., 2007; Halmemies-Beauchet-Filleau et al., 2011) or fish oil (0.0076; Shingfield et al., 2003).

Trans-11 18:1 absorbed in the small intestine is preferentially incorporated into plasma triacylglycerols (Tyburczy et al., 2008; Halmemies-Beauchet-Filleau et al., 2013a) that serve as a substrate for milk fat synthesis (Shingfield et al., 2010). Such a mechanism explains the relatively high apparent transfer from the gut into milk and increases in milk fat trans-11 18:1 and cis-9,trans-11 CLA concentrations to increases in postruminal trans-11 18:1 supply (Tyburczy et al., 2008; Halmemies-Beauchet-Filleau et al., 2013a). Milk fat total CLA concentration typically varies between 0.3 and $0.5 \mathrm{~g} / 100 \mathrm{~g}$ of total FA (Lindmark-Månsson, 2008), but on diets supplemented with fish oil or high amounts of plant oil, enrichment of CLA can approach $3.6 \mathrm{~g} / 100 \mathrm{~g}$ of total FA (Dewhurst et al., 2006). In the present study, the $6 \% \mathrm{CO}$ treatment elevated milk fat total CLA to a concentration of $4.3 \mathrm{~g} / 100 \mathrm{~g}$ of total FA, which when considered in conjunction with the increase in trans-11 18:1 would be expected to increase the CLA status of human consumers (Shingfield and Wallace, 2014).

Dietary plant oil supplements often elevate milk fat trans-10 18:1 concentration (Chilliard et al., 2009; Shingfield et al., 2013). However, milk fat trans-10 18:1 concentration decreased quadratically in response to $\mathrm{CO}$ treatments from 1.2 to $0.8 \mathrm{~g} / 100 \mathrm{~g}$ of total FA. In earlier studies, CO supplements have been shown to cause a marginal enrichment in milk fat trans-10 18:1 concentration in cows fed grass silage or RCSbased diets of between 0.06 to 0.14 percentage units (Halmemies-Beauchet-Filleau et al., 2011; Bayat et al., 2015). However, camelina expeller or camelina meal has resulted in higher increases in milk fat trans-10 18:1 concentration in cows fed diets based on grass silage or RCS (from 0.60 to 0.89 percentage units; Mihhejev et al., 2007; Halmemies-Beauchet-Filleau et al., 2011) and corn silage-based diets (10 percentage units; Hurtaud and Peyraud, 2007). The use of camelina expeller as a protein source probably accounts for the elevated trans-10 18:1 concentration on the control diet, whereas lipid from CO appears to have a rather minor influence on milk fat trans-10 18:1 concentration in cows fed diets based on grass silage or RCS.

The secretion of 18:0, the end product of the biohydrogenation of 18-carbon unsaturated FA (Shingfield et al., 2010) in milk, was similar across all diets despite the rather high intake of 18-carbon unsaturated FA (from 477 to $676 \mathrm{~g} / \mathrm{d}$ ) across diets. For all treatments, the concentration of 18:0 of 4 to $5 \mathrm{~g} / 100 \mathrm{~g}$ of total FA was lower than typical for bovine milk fat ( 8 to $14 \mathrm{~g} / 100$ g of total FA; Jensen, 2002; Lindmark-Månsson, 2008; Chilliard et al., 2009). Nevertheless, the relative proportions of 18:0 in milk fat are similar to earlier reports for milk from cows fed diets containing camelina seeds, meal, or expeller (from 3 to $7 \mathrm{~g} / 100 \mathrm{~g}$ of FA; Hurtaud and Peyraud, 2007; Mihhejev et al., 2007; HalmemiesBeauchet-Filleau et al., 2011) or fish oil (from 3 to 9 g/100 g of FA; Shingfield et al., 2013). Consistent with a high proportion (between 44 and $69 \%$ ) of 18:0 taken up by mammary gland being desaturated to cis-9 18:1 (Shingfield et al., 2010; Halmemies-Beauchet-Filleau et 
al., 2013a), treatments had no effect on cis-9 18:1 output in milk. For all treatments, the proportion of cis-9 18:1 in milk fat was relatively low, approximately 10 $\mathrm{g} / 100 \mathrm{~g}$ of total FA compared with concentrations of 12 to $31 \mathrm{~g} / 100 \mathrm{~g}$ of total FA reported for milk from cows fed diets containing plant oils (Shingfield et al., 2013). Earlier investigations reported relatively low milk fat cis-9 18:1 concentrations of between 14 and $15 \mathrm{~g} / 100$ $\mathrm{g}$ of FA in cows fed dietary supplements of camelina meal and camelina expeller (Mihhejev et al., 2007; Hurtaud and Peyraud, 2007; Halmemies-Beauchet-Filleau et al., 2011), but not in response to camelina oil (17 to $24 \mathrm{~g} / 100 \mathrm{~g}$ of FA; Halmemies-Beauchet-Filleau et al., 2011; Bayat et al., 2015). In cows fed diets supplemented with fish oil or marine algae milk fat, cis-9 18:1 concentrations can be as low as $6 \mathrm{~g} / 100 \mathrm{~g}$ of FA (Shingfield et al., 2013).

The lack of increase in milk 18:0 and cis-9 18:1 secretion, enrichment of trans 18:1 and 18:2 intermediates in milk fat, and the absence of alterations in the main biohydrogenation pathways in response to $\mathrm{CO}$ treatments suggest that ruminal metabolism of unsaturated 18-carbon FA in camelina may differ compared with metabolism of lipid from other plant sources. Direct comparisons suggest that camelina oilseeds, but not $\mathrm{CO}$, contain additional components that may interfere with the complete biohydrogenation of 18-carbon unsaturates to 18:0 in the rumen (Halmemies-BeauchetFilleau et al., 2011). Milk fat concentrations of 18:0 and cis-9 18:1 were lower and the relative proportions of trans-11-containing biohydrogenation intermediates were higher from cows fed RCS-based diets supplemented with similar amounts of lipid as camelina expeller compared with CO (Halmemies-Beauchet-Filleau et al., 2011). Similar changes in milk 18-carbon FA have been reported for camelina expeller relative to rapeseed or linseed expeller in cows fed grass silage-based diets (Mihhejev et al., 2007). Supplementing corn silage-based diets with camelina seed or meal has also been shown to markedly decrease 18:0 and cis-9 18:1 secretion in milk with a concominant increase in milk fat trans-11 18:1 and cis-9,trans-11 CLA concentrations (Hurtaud and Peyraud, 2007). Furthermore, replacing rapeseed meal with camelina expeller in rations based on a mixture of alfalfa silage, grass silage, and meadow hay has been reported to cause similar changes in milk 18-carbon FA composition in lactating sheep (Szumacher-Strabel et al., 2011).

Ruminal bacteria capable of biohydrogenation are classified into groups A and B. Group A bacteria reduce LA and ALA to trans-18:1, but only group B bacteria are able to reduce trans-18:1 to 18:0 (Harfoot and Hazlewood, 1988). Because of the presence of camelina expeller in all experimental diets, it is plausible that the biohydrogenating activity of group B bacteria in the rumen was potentially suppressed. Milk fat trans11,cis-15 18:2 concentration was also relatively high on all treatments (from 1.7 to $5.8 \mathrm{~g} / 100 \mathrm{~g}$ of total FA) consistent with a partial inhibition of the major pathway of ALA biohydrogenation in the rumen that involves the initial formation of cis-9,trans-11,cis-15 18:3 that is sequentially reduced to yield trans-11,cis-15 18:2 and trans-11 18:1 as intermediates (Shingfield et al., 2010; Honkanen et al., 2016). A relatively high abundance of trans-11,cis-15 18:2 has also been detected in milk from cows fed intact or processed camelinaseeds (0.6 to 2.5 $\mathrm{g} / 100 \mathrm{~g}$ of total FA; Hurtaud and Peyraud, 2007; Mihhejev et al., 2007; Halmemies-Beauchet-Filleau et al., 2011). In contrast, the concentrations of trans-11, cis-15 18:2 in milk from diets containing $\mathrm{CO}$ have been much lower (from 0.2 to $0.4 \mathrm{~g} / 100 \mathrm{~g}$ of total FA; HalmemiesBeauchet-Filleau et al., 2011; Bayat et al., 2015). Direct measurements of ruminal lipid metabolism of camelina oilseeds and camelina oil in vitro and confirmation in vivo are required to confirm the potential bioactivity in the rumen and to identify one or more active components in camelinaseeds.

$\boldsymbol{O B C F A}$. The OBCFA in milk originate primarily from the digestion of microbial OBCFA synthesized de novo in the rumen (Vlaeminck et al., 2006). Changes in the relative proportions of OBCFA in milk may, at least in part, be associated with alterations in microbial counts or in the relative abundance of specific populations of bacteria and protozoa in the rumen. Inclusion of $\mathrm{CO}$ in concentrates linearly decreased the concentration of all saturated 14- to 18-carbon OBCFA. Such changes may indicate that $\mathrm{CO}$ alters the rumen microbial community due to the inhibitory effects of PUFA on microbial growth (Ivan et al., 2001; Maia et al., 2007). However, CO supplementation was found to have no effect on ruminal protozoal counts in this or an earlier investigation (Bayat et al., 2015). It is also possible that the higher availability of 18-carbon NEFA in the rumen from $\mathrm{CO}$ promoted direct incorporation of dietary FA into microbial lipid at expense of bacterial FA synthesis de novo (Sauvant and Bas, 2001), such that the outflow of OBCFA may be altered without affecting total microbial numbers.

16-Carbon trans $\boldsymbol{F A}$. Milk fat 16-carbon trans FA are thought to originate from incomplete biohydrogenation of dietary 16-carbon unsaturated FA in the rumen (Shingfield and Wallace, 2014), and $\beta$-oxidation of 18-carbon FA (Destaillats et al., 2000). Small amounts of trans 16:1 ( $\Delta 6$ to 13$)$ are known to escape the rumen (Shingfield et al., 2012; Halmemies-Beauchet-Filleau et al., 2013b). However, silage and concentrates did not 
contain high proportions of 16-carbon unsaturated FA (less than 3.5 and $0.96 \mathrm{~g} / 100 \mathrm{~g}$ of total FA, respectively), suggesting that the appearance of 16-carbon trans FA in milk in the present study may have originated primarily from $\beta$-oxidation of 18 -carbon precursors. Both trans-9 16:1 and trans-11 18:1 were increased approximately 2.0 -fold in milk fat in response to incremental CO supplementation. Recent reports suggest that trans-9 16:1 can be elongated to trans-11 18:1 and subsequently desaturated to cis-9,trans-11 CLA in bovine adipocytes (Shingfield and Wallace, 2014). It is notable that the magnitude of $\Delta 9,1316: 2$ and $\Delta 11,15$ 18:2 enrichment in milk fat to CO were similar.

20:0 and 20-Carbon MUFA. Camelina lipid is relatively abundant in cis-11 20:1 ( $\sim 15 \mathrm{~g} / 100 \mathrm{~g}$ of total FA; Zubr, 2003b; Bayat et al., 2015). In the present study, CO increased the intake and secretion of cis-11 20:1 in milk. However, the increase in cis-11 20:1 intake from 34 to $132 \mathrm{~g} / \mathrm{d}$ to $\mathrm{CO}$ treatments was not accompanied by an increase in 20:0 and cis-9 20:1 output in milk, whereas that of trans-11 20:1 was higher. These findings suggest that the inclusion of camelina expeller in all experimental diets may have inhibited the complete biohydrogenation of 20-carbon unsaturated FA in the rumen.

Desaturation. Milk fat concentration ratios of product to substrate for SCD1 were marginally decreased in response to CO. Part of the decrease may reflect a higher availability of PUFA at the mammary gland inhibiting SCD1 activity (Chilliard et al., 2000). Several biohydrogenation intermediates including trans-10, cis-12 CLA, trans-10,trans-12 CLA, and trans9,trans-11 CLA in addition to 20- and 22-carbon n-3 FA are thought to lower SCD1 activity in the bovine mammary gland (Angulo et al., 2012). In the present study, the concentration of these CLA isomers in milk fat declined linearly in response to $\mathrm{CO}$ supplementation, but 3.2- and 2.7-fold linear increases in milk fat cis-11,cis-14,cis-17 20:3 and cis-13,cis-16,cis-19 22:3 concentrations, respectively, were detected.

In the present study, the ratio of cis-9,trans-11 CLA to trans-11 18:1 concentration in milk ranged between 0.41 and 0.49 , which is in accordance with earlier reports (between 0.35 and 0.60; Chilliard et al., 2009; Halmemies-Beauchet-Filleau et al., 2011, 2013a). In cows, mammary SCD1 gene expression and the concentration ratio of cis-9,trans-11 CLA to trans-11 18:1 in milk has been found to decrease in response to linseed oil (mean ratio 0.31) or linseed and DHA-enriched algae (0.16) compared with the same diet containing saturated FA from palm oil (0.41; Angulo et al., 2012). It therefore appears unlikely that dietary supplements of $\mathrm{CO}$ have a substantive negative effect on mammary SCD1 activity, with the implication that the majority of cis-9,trans-11 CLA in milk on all experimental diets originates from desaturation of trans-11 18:1 in the mammary gland.

\section{CONCLUSIONS}

Incremental amounts of $\mathrm{CO}$ in concentrate supplements lowered silage and total diet DM intake, which, together with a decrease in plasma glucose and insulin concentrations and lower yields of ECM, milk protein, and lactose, suggests that high levels of $\mathrm{CO}$ in the diet may result in an inadequacy of energy supply to meet the requirements of high-yielding dairy cows. Incremental CO supplementation compromised the sensory attributes of milk perhaps due to marked changes in milk fat composition. Inclusion of $\mathrm{CO}$ in concentrates containing oil-rich camelina expeller as a protein source altered milk FA composition, characterized by a relatively high enrichment of 18-carbon biohydrogenation intermediates of trans-11 pathway, including trans-11 18:1 and cis-9,trans-11 CLA, and a decrease in short- and medium-chain SFA and biohydrogenation intermediates of the trans-10 pathway, in the absence of changes in the relative proportions of 18:0, cis-9 18:1, LA, and ALA. Indirect comparisons of milk fat composition measured in the present experiment and earlier investigations suggest that one or more components in camelina expeller may inhibit the complete biohydrogenation of 18-carbon unsaturated $\mathrm{FA}$ in the rumen. Dietary CO supplements can be used to alter milk FA composition, but in high amounts may depress DMI and milk yield. Concentrates containing camelina expeller and $2 \%$ CO supplying an additional $240 \mathrm{~g}$ of oil/d could be used for the commercial production of low-saturated milk from grass silage and RCS-based diets without major adverse effects on animal performance compared with an unsupplemented control diet.

\section{ACKNOWLEDGMENTS}

This article is dedicated to the memory of the late Professor Kevin J. Shingfield with gratitude for his inspiration, guidance, and commitment to this work and, above all, for his warm and everlasting friendship. The authors gratefully acknowledge the contribution of staff at the University of Helsinki research farm in Viikki (Finland) for the care of experimental animals under the supervision of Juha Suomi, and chemical analysis undertaken in the laboratory under the guidance of Leena Luukkainen. Valuable contributions of laboratory staff at Luke to sample lipid analysis and the assistance of Anneli Pakarinen, Sini Salomaa, Walter König, and Saana Orkola during the collection of experimental samples 
is very much appreciated. Formulation and provision of experimental concentrates by Raisio Feed Ltd. (Raisio, Finland) under the guidance of Merja Holma and determination of milk sensory quality and butter storage properties in the laboratories of Valio Ltd. (Helsinki, Finland) supervised by Juha Nousiainen are also acknowledged and appreciated. This work was supported in part by the Finnish Funding Agency for Technology and Innovation (Helsinki, Finland), Valio Ltd., Raisio Feed Ltd., and Kemira Ltd. (Helsinki, Finland).

\section{REFERENCES}

Ahvenjärvi, S., A. Vanhatalo, P. Huhtanen, and T. Varvikko. 2000. Determination of reticulo-rumen and whole-stomach digestion in lactating cows by omasal canal or duodenal sampling. Br. J. Nutr. 83:67-77.

Allen, M. S. 2000. Effects of diet on short-term regulation of feed intake by lactating dairy cows. J. Dairy Sci. 83:1598-1624.

Angulo, J., L. Mahecha, K. Nuernberg, G. Nuernberg, D. Dannenberger, M. Olivera, M. Boutinaud, C. Leroux, E. Albrecht, and L. Bernard. 2012. Effects of polyunsaturated fatty acids from plant oils and algae on milk fat yield and composition are associated with mammary lipogenic and SREBF1 gene expression. Animal 6:1961-1972.

Baumgard, L. H., J. K. Sangster, and D. E. Bauman. 2001. Milk fat synthesis in dairy cows is progressively reduced by increasing supplemental amounts of trans-10, cis-12 conjugated linoleic acid (CLA). J. Nutr. 131:1764-1769.

Bayat, A. R., P. Kairenius, T. Stefański, H. Leskinen, S. ComtetMarre, E. Forano, F. Chaucheyras-Durand, and K. J. Shingfield. 2015. Effect of camelina oil or live yeasts (Saccharomyces cerevisiae) on ruminal methane production, rumen fermentation, and milk fatty acid composition in lactating cows fed grass silage diets. J. Dairy Sci. 98:3166-3181.

Bell, J. A., J. M. Griinari, and J. J. Kennelly. 2006. Effect of safflower oil, flaxseed oil, monensin, and vitamin E on concentration of conjugated linoleic acid in bovine milk fat. J. Dairy Sci. 89:733-748.

Benchaar, C., F. Hassanat, R. Martineau, and R. Gervais. 2015. Linseed oil supplementation to dairy cows fed diets based on red clover silage or corn silage: Effects on methane production, rumen fermentation, nutrient digestibility, $\mathrm{N}$ balance, and milk production. J. Dairy Sci. 98:7993-8008.

Bickerstaffe, R., E. F. Annison, and J. L. Linzell. 1974. The metabolism of glucose, acetate, lipids and amino acids in lactating dairy cows. J. Agric. Sci. (Camb.) 82:71-85.

Cant, J. P., E. J. DePeters, and R. L. Baldwin. 1993. Mammary uptake of energy metabolites in dairy cows fed fat and its relationship to milk protein depression. J. Dairy Sci. 76:762-774.

Chilliard, Y., A. Ferlay, R. M. Mansbridge, and M. Doreau. 2000. Ruminant milk plasticity: Nutritional control of saturated, polyunsaturated, trans and conjugated fatty acids. Ann. Zootech. 49:181-205.

Chilliard, Y., C. Martin, J. Ruel, and M. Doreau. 2009. Milk fatty acids in dairy cows fed whole crude linseed, extruded linseed, or linseed oil, and their relationship with methane output. J. Dairy Sci. 92:5199-5211.

Destaillats, F., R. L. Wolff, D. Precht, and J. Molkentin. 2000. Study of individual trans- and cis-16:1 isomers in cow, goat and ewe cheese fats by gas-liquid chromatography with emphasis on the trans- $\Delta 3$ isomer. Lipids 35:1027-1032.

Dewhurst, R. J., K. J. Shingfield, M. R. F. Lee, and N. D. Scollan. 2006. Increasing the concentrations of beneficial fatty acids in milk produced by dairy cows in high forage systems. Anim. Feed Sci. Technol. 131:168-206.

Doreau, M., and Y. Chilliard. 1997. Digestion and metabolism of dietary fat in farm animal. Br. J. Nutr. 78:S15-S35.
Drackley, J. K., T. H. Klusmeyer, A. M. Trusk, and J. H. Clark. 1992. Infusion of long-chain fatty acids varying in saturation and chain length into the abomasum of lactating dairy cows. J. Dairy Sci. $75: 1517-1526$.

Drackley, J. K., T. R. Overton, G. Ortiz-Gonzalez, A. D. Beaulieu, D. M. Barbano, J. M. Lynch, and E. G. Perkins. 2007. Responses to increasing amounts of high-oleic sunflower fatty acids infused into the abomasum of lactating dairy cows. J. Dairy Sci. 90:5165-5175.

Early, R. 1998. The Technology of Dairy Products. Blackie Acad. Professional, London, UK.

Edmonson, A. J., I. J. Lean, L. D. Weaver, T. Farver, and G. Webster. 1989. A body condition scoring chart for Holstein dairy cows. J. Dairy Sci. 72:68-78.

European Union. 1986. Council Directive 86/609/EEC on the approximation of laws, regulations and administrative provisions of the Member States regarding the protection of animals used for experimental and other scientific purposes. Off. J. L. 358:1-28.

FAO (Food and Agriculture Organization of the United Nations). 2010. Fats and fatty acids in human nutrition. Report of an expert consultation. FAO food and nutrition paper 91. FAO, Rome, Italy. Accessed April 5, 2016. http://www.fao.org/3/a-i1953e.pdf.

Gagliostro, G., Y. Chilliard, and M.-J. Davicco. 1991. Duodenal rapeseed oil infusion in early and midlactation cows. 3. Plasma hormones and mammary apparent uptake of metabolites. J. Dairy Sci. 74:1893-1903.

Glasser, F., P. Schmidely, D. Sauvant, and M. Doreau. 2008. Digestion of fatty acids in ruminants: A meta-analysis of flows and variation factors: 2. C18 fatty acids. Animal 2:691-704.

Halliwell, B., and S. Chirico. 1993. Lipid peroxidation: Its mechanism, measurement, and significance. Am. J. Clin. Nutr. 57:715S-724S.

Halmemies-Beauchet-Filleau, A., P. Kairenius, S. Ahvenjärvi, V Toivonen, P. Huhtanen, A. Vanhatalo, D. I. Givens, and K. J. Shingfield. 2013a. Effect of forage conservation method on plasma lipids, mammary lipogenesis, and milk fatty acid composition in lactating cows fed diets containing a 60:40 forage-to-concentrate ratio. J. Dairy Sci. 96:5267-5289.

Halmemies-Beauchet-Filleau, A., T. Kokkonen, A.-M. Lampi, V. Toivonen, K. J. Shingfield, and A. Vanhatalo. 2011. Effect of plant oils and camelina expeller on milk fatty acid composition in lactating cows fed diets based on red clover silage. J. Dairy Sci. 94:4413-4430.

Halmemies-Beauchet-Filleau, A., A. Vanhatalo, V. Toivonen, T. Heikkilä, M. R. F. Lee, and K. J. Shingfield. 2013b. Effect of replacing grass silage with red clover silage on ruminal lipid metabolism in lactating cows fed diets containing a 60:40 forage-to-concentrate ratio. J. Dairy Sci. 96:5882-5900.

Halmemies-Beauchet-Filleau, A., A. Vanhatalo, V. Toivonen, T. Heikkilä, M. R. F. Lee, and K. J. Shingfield. 2014. Effect of replacing grass silage with red clover silage on nutrient digestion, nitrogen metabolism, and milk fat composition in lactating cows fed diets containing a 60:40 forage-to-concentrate ratio. J. Dairy Sci. 97:3761-3776.

Harfoot, C. G., and G. P. Hazlewood. 1988. Lipid metabolism in the rumen. Pages 285-322 in The Rumen Microbial Ecosystem. P. N. Hobson, ed. Elsevier Science, London, UK.

Havemose, M. S., M. R. Weisbjerg, W. L. P. Bredie, and J. H. Nielsen. 2004. Influence of feeding different types of roughage on the oxidative stability of milk. Int. Dairy J. 14:563-570.

Honkanen, A. M., H. Leskinen, V. Toivonen, N. McKain, R. J. Wallace, and K. J. Shingfield. 2016. Metabolism of $\alpha$-linolenic acid during incubations with strained bovine rumen contents: Products and mechanisms. Br. J. Nutr. 115:2093-2105.

Hurtaud, C., and J. L. Peyraud. 2007. Effects of feeding camelina (seeds or meal) on milk fatty acid composition and butter spreadability. J. Dairy Sci. 90:5134-5145.

IDF. 2004. Standard 6: Milkfat products and butter-Determination of fat acidity. International Dairy Federation, Brussels, Belgium.

Ivan, M., P. S. Mir, K. M. Koenig, L. M. Rode, L. Neill, T. Entz, and Z. Mir. 2001. Effects of dietary sunflower seed oil on rumen protozoa population and tissue concentration of conjugated linoleic acid in sheep. Small Rumin. Res. 41:215-227. 
Jensen, R. G. 2002. The composition of bovine milk lipids: January 1995 to December 2000. J. Dairy Sci. 85:295-350.

Kanno, C., K. Yamauchi, and T. Tsugo. 1968. Occurrence of $\gamma$-tocopherol and variation of a- and $\gamma$-tocopherol in bovine milk fat. J. Dairy Sci. 51:1713-1719.

Kliem, K. E., and K. J. Shingfield. 2016. Manipulation of milk fatty acid composition in lactating cows: Opportunities and challenges. Eur. J. Lipid Sci. Technol. 118:1661-1683. https://doi. org/10.1002/ejlt.201400543.

Koivunen, E., S. Jaakkola, T. Heikkilä, A.-M. Lampi, A. HalmemiesBeauchet-Filleau, M. R. F. Lee, A. L. Winters, K. J. Shingfield, and A. Vanhatalo. 2015. Effect of plant species, stage of maturity, and level of formic acid addition on lipolysis, lipid content, and fatty acid composition during ensiling. J. Anim. Sci. 93:4408-4423.

Kokkonen, T., M. Tuori, V. Leivonen, and L. Syrjälä-Qvist. 2000. Effect of silage dry matter content and rapeseed meal supplementation on dairy cows. 1. Milk production and feed utilisation. Anim. Feed Sci. Technol. 84:213-228.

Korhonen, M., A. Vanhatalo, and P. Huhtanen. 2002. Effect of protein source on amino acid supply, milk production, and metabolism of plasma nutrients in dairy cows fed grass silage. J. Dairy Sci. 85:3336-3351.

Lindmark-Månsson, H. 2008. Fatty acids in bovine milk fat. Food Nutr. Res. 52: https://doi.org/10.3402/fnr.v52i0.1821.

Litherland, N. B., S. Thire, A. D. Beaulieu, C. K. Reynolds, J. A. Benson, and J. K. Drackley. 2005. Dry matter is decreased more by abomasal infusion of unsaturated free fatty acids than by unsaturated triglycerides. J. Dairy Sci. 88:632-643.

Lock, A. L., and K. J. Shingfield. 2004. Optimising milk composition. Pages 107-188 in Dairying-Using Science to Meet Consumers Needs. E. Kebreab, J. Mills, and D. E. Beever, ed. Br. Soc. Anim. Sci. Publ. 29. Nottingham University Press, Loughborough, UK.

Luke. 2015. Finnish feed tables and feeding recommendations. Accessed Dec. 22, 2015. https://portal.mtt.fi/portal/page/portal/ Rehutaulukot/feed_tables_english.

Maia, M. R. G., L. C. Chaudhary, L. Figeres, and R. J. Wallace. 2007. Metabolism of polyunsaturated fatty acids and their toxicity to the microflora of the rumen. Antonie van Leeuwenhoek 91:303-314.

Mihhejev, K., M. Henno, M. Ots, E. Rihma, P. Elias, S. Kuusik, and O. Kärt. 2007. Effects of fat-rich oil cakes on cheese fatty acid composition, and on cheese quality. Vet. Zootec. 40:55-61.

Mosley, E. E., B. Shafii, P. J. Moate, and M. A. McGuire. 2006. Cis-9, trans-11 conjugated linoleic acid is synthesized directly from vaccenic acid in lactating dairy cattle. J. Nutr. 136:570-575.

Parodi, P. W. 2001. Cows' milk components with anti-cancer potential. Aust. J. Dairy Technol. 56:65-73.

Perk, J., G. De Backer, H. Gohlke, I. Graham, Z. Reiner, W. M. M. Verschuren, C. Albus, P. Benlian, G. Boysen, R. Cifkova, C. Deaton, S. Ebrahim, M. Fisher, G. Germano, R. Hobbs, A. Hoes, S. Karadeniz, A. Mezzani, E. Prescott, L. Ryden, M. Scherer, M. Syvänne, W. J. M. Scholte Op Reimer, C. Vrints, D. Wood, J. L. Zamorano, and F. Zannad. 2012. European guidelines on cardiovascular disease prevention in clinical practice (version 2012). The fifth joint task force of the European society of cardiology and other societies on cardiovascular disease prevention in clinical practice (constituted by representatives of nine societies and by invited experts). Eur. Heart J. 33:1635-1701.

Pikul, J., J. Wojtowski, R. Dankow, J. Teichert, G. Czyzak-Runowska, D. Cais-Sokolinska, A. Cieslak, M. Szumacher-Strabel, and E. Bagnicka. 2014. The effect of false flax (Camelina sativa) cake dietary supplementation in dairy goats on fatty acid profile of kefir. Small Rumin. Res. 122:44-49.

Rego, O. A., S. P. Alves, L. M. S. Antunes, H. J. D. Rosa, C. F. M. Alfaia, J. A. M. Prates, A. R. J. Cabrita, A. J. M. Fonseca, and R. J. B. Bessa. 2009. Rumen biohydrogenation-derived fatty acids in milk fat from grazing dairy cows supplemented with rapeseed, sunflower, or linseed oils. J. Dairy Sci. 92:4530-4540.

Relling, A. E., and C. K. Reynolds. 2007. Feeding rumen-inert fats differing in their degree of saturation decreases intake and increases plasma concentrations of gut peptides in lactating dairy cows. J. Dairy Sci. 90:1506-1515.
Roy, A., A. Ferlay, K. J. Shingfield, and Y. Chilliard. 2006. Examination of the persistency of milk fatty acid composition responses to plant oils in cows given different basal diets, with particular emphasis on trans-C18:1 fatty acids and isomers of conjugated linoleic acid. Anim. Sci. 82:479-492.

Sauvant, D., and P. Bas. 2001. La digestion des lipides chez les ruminants. (Lipid digestion in ruminants). INRA Prod. Anim. 14:303310.

Schmidely, P., F. Glasser, M. Doreau, and D. Sauvant. 2008. Digestion of fatty acids in ruminants: A meta-analysis of flows and variation factors. 1. Total fatty acids. Animal 2:677-690.

Schröder, M., and W. Vetter. 2011. GC/EI-MS Determination of the diastereomer distribution of phytanic acid in food samples. J. Am. Oil Chem. Soc. 88:341-349.

Schwab, C. G., P. Huhtanen, C. W. Hunt, and T. Hvelplund. 2005. Nitrogen requirements of cattle. Pages 13-70 in Nitrogen and Phosphorus Nutrition of Cattle-Reducing the Environmental Impact of Cattle Operations. E. Pfeffer and A. N. Hristov, ed. CABI Publishing, Wallingford, UK.

Selim, S., S. Salin, J. Taponen, A. Vanhatalo, T. Kokkonen, and K. T. Elo. 2014. Prepartal dietary energy alters transcriptional adaptations of the liver and subcutaneous adipose tissue of dairy cows during the transition period. Physiol. Genomics 46:328-337.

Shingfield, K. J., S. Ahvenjärvi, V. Toivonen, A. Ärölä, K. V. V. Nurmela, P. Huhtanen, and J. M. Griinari. 2003. Effect of dietary fish oil on biohydrogenation of fatty acids and milk fatty acid content in cows. Anim. Sci. 77:165-179.

Shingfield, K. J., S. Ahvenjärvi, V. Toivonen, A. Vanhatalo, P. Huhtanen, and J. M. Griinari. 2008a. Effect of incremental levels of sunflower-seed oil in the diet on ruminal lipid metabolism in lactating cows. Br. J. Nutr. 99:971-983.

Shingfield, K. J., L. Bernard, C. Leroux, and Y. Chilliard. 2010. Role of trans fatty acids in the nutritional regulation of mammary lipogenesis in ruminants. Animal 4:1140-1166.

Shingfield, K. J., M. Bonnet, and N. D. Scollan. 2013. Recent developments in altering the fatty acid composition of ruminant-derived foods. Animal 77:132-162.

Shingfield, K. J., Y. Chilliard, V. Toivonen, P. Kairenius, and D. I. Givens. 2008b. Trans fatty acids and bioactive lipids in ruminant milk. Pages 3-65 in Bioactive Components of Milk, Advances in Experimental Medicine and Biology. Vol. 606. Z. Bösze, ed. Springer, New York, NY.

Shingfield, K. J., P. Kairenius, A. Ärölä, D. Paillard, S. Muetzel, S. Ahvenjärvi, A. Vanhatalo, P. Huhtanen, V. Toivonen, J. M. Griinari, and R. J. Wallace. 2012. Dietary fish oil supplements modify ruminal biohydrogenation, alter the fow of fatty acids at the omasum, and induce changes in the ruminal Butyrivibrio population in lactating cows. J. Nutr. 142:1437-1448.

Shingfield, K. J., and R. J. Wallace. 2014. Synthesis of conjugated linoleic acid in ruminants and humans. Pages 1-64 in Conjugated Linoleic Acids and Conjugated Vegetable Oils. B. Sels and A. Philippaerts, ed. Royal Society of Chemistry, London, UK.

Sjaunja, L. O., L. Baevre, L. Junkarinen, J. Pedersen, and J. Setälä. 1990. A Nordic proposal for an energy corrected milk (ECM) formula. Pages 156-157 in Proc. 27th Biennial Session Int. Committee for Animal Recording. ICAR, Paris, France. Pudoc, Wageningen, the Netherlands.

Steinshamn, H. 2010. Effect of forage legumes on feed intake, milk production and milk quality - A review. Anim. Sci. Pap. Rep. $28: 195-206$.

Szumacher-Strabel, M., A. Cieślak, P. Zmora, E. Pers-Kamczyc, S. Bielińska, M. Stanisz, and J. Wojtowski. 2011. Camelina sativa cake improved unsaturated fatty acids in ewe's milk. J. Sci. Food Agric. 91:2031-2037.

Tucker, R. M., R. D. Mattes, and C. A. Running. 2014. Mechanisms and effects of "fat taste" in humans. Biofactors 40:313-326.

Tyburczy, C., A. L. Lock, D. A. Dwyer, F. Destaillats, Z. Mouloungui, L. Candy, and D. E. Bauman. 2008. Uptake and utilization of trans octadecenoic acids in lactating dairy cows. J. Dairy Sci. 91:3850-3861. 
USDA-USDHHS. 2010. Dietary Guidelines for Americans. 7th ed. US Government Printing Office, Washington, DC.

Ueda, K., A. Ferlay, J. Chabrot, J. J. Loor, Y. Chilliard, and M. Doreau. 2003. Effect of linseed oil supplementation on ruminal digestion in dairy cows fed diets with different forage:concentrate ratios. J. Dairy Sci. 86:3999-4007.

Vanhatalo, A., P. Huhtanen, V. Toivonen, and T. Varvikko. 1999. Response of dairy cows fed grass silage diets to abomasal infusion of histidine alone or in combinations with methionine and lysine. J. Dairy Sci. 82:2674-2685.

Vanhatalo, A., K. Kuoppala, S. Ahvenjärvi, and M. Rinne. 2009. Effects of feeding grass or red clover silage cut at two maturity stages in dairy cows. 1. Nitrogen metabolism and supply of amino acids. J. Dairy Sci. 92:5620-5633.

Vlaeminck, B., V. Fievez, A. R. J. Cabrita, A. J. M. Fonseca, and R. J. Dewhurst. 2006. Factors affecting odd- and branched-chain fatty acids in milk: A review. Anim. Feed Sci. Technol. 131:389-417.
Weiss, W. P., and D. J. Wyatt. 2003. Effect of dietary fat and vitamin $\mathrm{E}$ on $\alpha$-tocopherol in milk from dairy cows. J. Dairy Sci 86:3582-3591.

Yang, S. L., D. P. Bu, J. Q. Wang, Z. Y. Hu, D. Li, H. Y. Wei, L. Y. Zhou, and J. J. Loor. 2009. Soybean oil and linseed oil supplementation affect profiles of ruminal microorganisms in dairy cows. Animal 3:1562-1569.

Zubr, J. 2003a. Qualitative variation of Camelina sativa seed from different locations. Ind. Crops Prod. 17:161-169.

Zubr, J. 2003b. Dietary fatty acids and amino acids of Camelina sativa seed. J. Food Qual. 26:451-462.

Zubr, J., and B. Matthäus. 2002. Effects of growth conditions on fatty acids and tocopherols in Camelina sativa oil. Ind. Crops Prod. $15: 155-162$. 